\title{
Estimating Streamflow and Base Flow Within the Nontidal Chesapeake Bay Riverine System
}

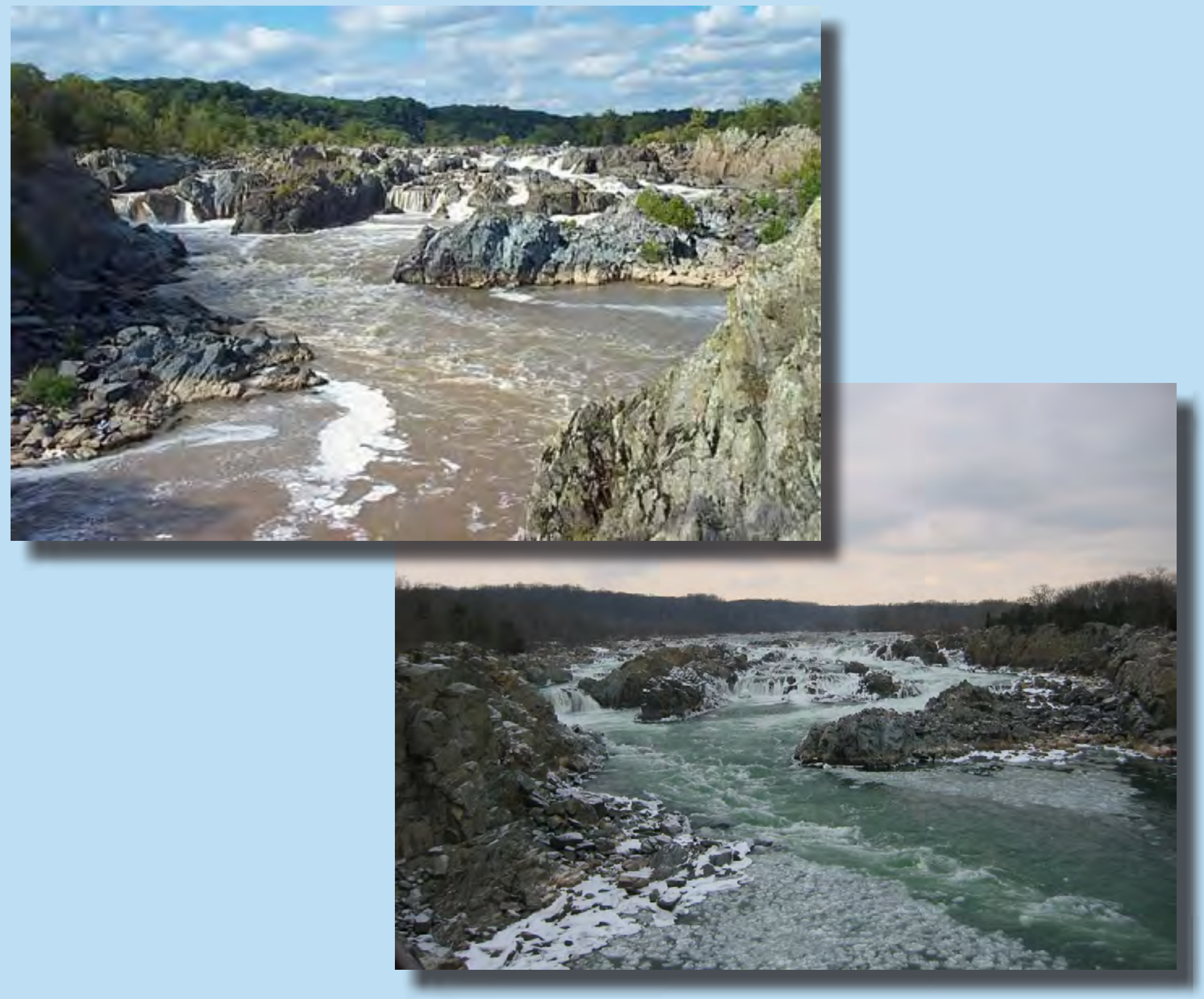

Scientific Investigations Report 2020-5055 
Cover. Great Falls, Potomac River, Maryland. Photographs by the National Park Service. 


\section{Estimating Streamflow and Base Flow Within the Nontidal Chesapeake Bay Riverine System}

By Patrick C. Buffington and Paul D. Capel

Scientific Investigations Report 2020-5055 


\title{
U.S. Department of the Interior \\ DAVID BERNHARDT, Secretary
}

\author{
U.S. Geological Survey \\ James F. Reilly II, Director
}

U.S. Geological Survey, Reston, Virginia: 2020

For more information on the USGS - the Federal source for science about the Earth, its natural and living resources, natural hazards, and the environment-visit https://www.usgs.gov or call 1-888-ASK-USGS.

For an overview of USGS information products, including maps, imagery, and publications, visit https://store.usgs.gov/.

Any use of trade, firm, or product names is for descriptive purposes only and does not imply endorsement by the U.S. Government.

Although this information product, for the most part, is in the public domain, it also may contain copyrighted materials as noted in the text. Permission to reproduce copyrighted items must be secured from the copyright owner.

Suggested citation:

Buffington, P.C., and Capel, P.D., 2020, Estimating streamflow and base flow within the nontidal

Chesapeake Bay riverine system: U.S. Geological Survey Scientific Investigations Report 2020-5055, 26 p.,

https://doi.org/10.3133/sir20205055.

Associated data for this publication:

Buffington, P.C., Capel, P.D., and Hopple, J.A., 2020, Datasets and scripts used for estimating streamflow and base flow within the nontidal Chesapeake Bay riverine system, water years 2006-15: U.S. Geological Survey data release, https://doi.org/10.5066/P906K5GZ.

U.S. Geological Survey, 2020, USGS water data for the Nation: U.S. Geological Survey National Water Information System database, accessed June 15, 2020, at https://doi.org/10.5066/F7P55KJN.

ISSN 2328-0328 (online) 


\section{Contents}

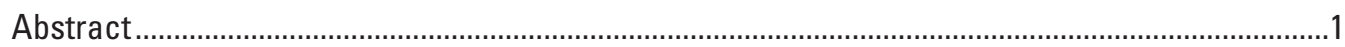

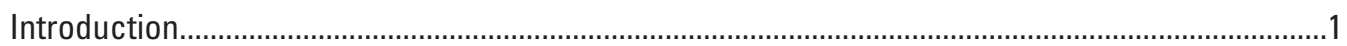

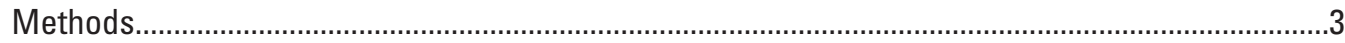

Estimating Streamflow at Ungaged Streams Using the Unit Flows in Networks of Channels Computer Application .....................................................................................

Reformatting the Unit Flows in Networks of Channels Computer Application Output

File as an Optimal Hydrograph Separation Software Package Input File .....................6

Calculating Base Flow Using Two Hydrograph-Separation Methods Using the

Optimal Hydrograph Separation Software Package ......................................................7

Animating the Modeled Streamflow and Base Flow ..............................................................

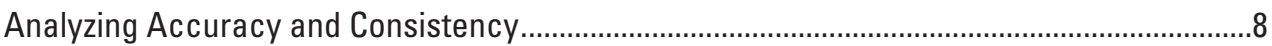

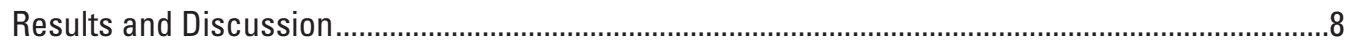

Statistics of Streamflow and Base Flow for Nontidal Areas of the Chesapeake Bay

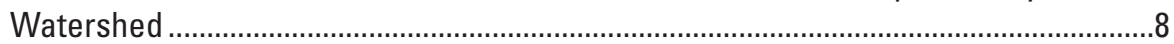

Accuracy of Streamflow Estimates ......................................................................................

Summary of Monthly Streamflow and Base-Flow Data for Selected Sites ...........................18

Comparison of Base-Flow Estimates.......................................................................................18

Animations of Streamflow and Base Flow ..........................................................................18

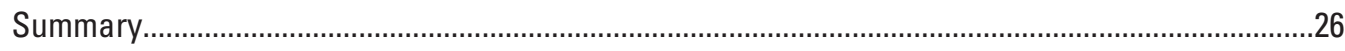

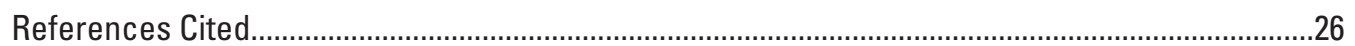

\section{Figures}

1. Map showing the Chesapeake Bay watershed..................................................................2

2. Screenshot showing a reproduction of the Unit Flows in Networks of Channels graphical user interface .....................................................................................................5

3. Screenshot showing the interactive map contained within the Unit Flows in Networks of Channels graphical user interface ............................................................6

4. Graph showing percent error of daily streamflows with respect to the drainage area ratio between the comparison gages and base gage......

5. Graph showing percent error of daily streamflows with respect to the flow distance from the comparison gages and base gage

6. Graph showing the Nash-Sutcliffe efficiency coefficients for daily streamflow with respect to the drainage area ratio between the comparison gages and base gage...

7. Graph showing the Nash-Sutcliffe efficiency coefficients for daily streamflow with respect to the flow distance from the comparison gages to the base gage.

8. Graph showing percent error of daily streamflows using the Potomac River at Washington, D.C., as the base gage compared to using Shenandoah River at Millville, West Virginia, as the base gage.

9. Graph showing the Nash-Sutcliffe efficiency coefficients for daily streamflow using Potomac River at Washington, D.C., as the base gage compared to using Shenandoah River at Millville, West Virginia, as the base gage.... 
10. Graphs showing the relation between modeled and measured monthly streamflows for the 10-year period from October 1, 2005, to September 30, 2015, for the six sites listed in

11. Graphs showing the relation between modeled and measured daily streamflows for the 10 -year period from October 1, 2005, to September 30, 2015 , for the six sites listed in

12. Boxplots showing 10 years of monthly streamflow and estimated base flow for the four of the sites listed in

13. Graphs showing the relation between monthly base-flow index values estimated by two hydrograph-separation methods for the 10-year period from October 1, 2005, to September 30, 2015, for the six sites listed in

14. Graphs showing the relation between daily base-flow index values estimated by two hydrograph-separation methods for the 10-year period from 0 ctober 1 , 2005, to September 30, 2015, for the six sites listed in

15. Screenshot showing the first frame of the monthly mean streamflow animation for the watershed of the Susquehanna River, upstream from Harrisburg, Pennsylvania

16. Screenshot showing the first frame of the monthly base-flow index animation for the watershed of the Susquehanna River, upstream from Harrisburg, Pennsylvania

17. Screenshot showing the first frame of the monthly mean streamflow animation for the nontidal Chesapeake Bay watershed outside of the Susquehanna watershed

18. Screenshot showing the first frame of the monthly base-flow index animation for the nontidal Chesapeake Bay watershed outside of the Susquehanna watershed

\section{Tables}

1. Selected streamgages that were used in this report

2. Selected sites for assessment of the accuracy of the modeled daily and monthly streamflow compared to the measured values and comparison of the two hydrograph-separation methods.

3. Summary of the assessment of the accuracy of the modeled daily and monthly streamflow compared to the measured values and the degree of the agreement between the daily and monthly base-flow index values calculated by two hydrograph-separation methods 


\section{Conversion Factors}

U.S. customary units to International System of Units

\begin{tabular}{|c|c|c|}
\hline Multiply & By & To obtain \\
\hline \multicolumn{3}{|c|}{ Length } \\
\hline mile (mi) & 1.609 & kilometer (km) \\
\hline \multicolumn{3}{|c|}{ Area } \\
\hline square mile $\left(\mathrm{mi}^{2}\right)$ & 2.590 & square kilometer $\left(\mathrm{km}^{2}\right)$ \\
\hline \multicolumn{3}{|c|}{ Flow rate } \\
\hline cubic foot per second $(\mathrm{ft} 3 / \mathrm{s})$ & 0.02832 & cubic meter per second $\left(\mathrm{m}^{3} / \mathrm{s}\right)$ \\
\hline
\end{tabular}

\section{Abbreviations}

$\begin{array}{ll}\text { BFI } & \text { Base-Flow Index } \\ \text { ComID } & \text { Common Identifiers number } \\ f & \text { turning point test factor } \\ \text { GUI } & \text { graphical user interface } \\ \text { HUC04 } & \text { 4-digit Hydrologic Unit Code } \\ \text { HUC12 } & \text { 12-digit Hydrologic Unit Code } \\ \text { N } & \text { number of days in a nonoverlapping block } \\ \text { NHD } & \text { National Hydrography Dataset } \\ \text { NHDPlusV2NHD Plus system, version 2 } \\ \text { NS } & \text { Nash-Sutcliffe } \\ \text { NWIS } & \text { National Water Information System } \\ \text { OHS } & \text { Optimal Hydrograph Separation } \\ \text { ParE } & \text { parameter estimation } \\ \text { PE } & \text { percent error } \\ \text { RDF } & \text { recursive digital filtering } \\ \text { UFINCH } & \text { Unit Flows in Networks of Channels } \\ \text { USGS } & \text { U.S. Geological Survey }\end{array}$





\title{
Estimating Streamflow and Base Flow Within the Nontidal Chesapeake Bay Riverine System
}

\author{
By Patrick C. Buffington ${ }^{1}$ and Paul D. Capel2
}

\begin{abstract}
Daily mean streamflow was estimated for all the nontidal parts of the Chesapeake Bay riverine system with the Unit Flows in Networks of Channels computer application using measured streamflow at the most downstream gage of selected rivers. The streamflows estimated by the Unit Flows in Networks of Channels computer application were aggregated at the 12-digit Hydrologic Unit Code level, after which base flow was estimated by two hydrograph-separation methods. Based on six sites selected for comparison, modeled streamflows are typically within an order of magnitude of measured streamflows, and monthly mean streamflows are in better agreement than daily streamflows. For the six selected sites, the base-flow values calculated by the two hydrograph-separation methods were compared. The monthly base-flow values also were in better agreement than the daily base-flow values. The modeled data were animated to better visualize spatial and temporal variability of streamflow and base-flow index.
\end{abstract}

\section{Introduction}

Most streamflow can be partitioned into two components: runoff (or stormflow) and base flow. The runoff component can change quickly in response to precipitation or snowmelt, but base flow is less variable and comes primarily from groundwater discharge into the stream. Base-flow information is important because it allows for estimating water availability, estimating the capacity of a stream to assimilate inputs, and assessing aquatic habitats (Santhi and others, 2008).

Base flow is difficult to distinguish from the runoff component using discrete measurements, so most estimates of base flow rely on hydrograph separation (Santhi and others, 2008). Hydrograph separation requires continuous streamflow data, which are generally only available at continuously operated streamgages. This requirement limits sites where the base-flow component can be estimated.

Several hydrograph-separation methods exist. Two common methods were used in this study: the Base-Flow

1 University of Minnesota.

2U.S. Geological Survey.
Index (BFI) program method (Wahl and Wahl, 1995) and the recursive digital filtering (RDF) method (Eckhardt, 2005). The BFI method is a computerized graphical method based on the determination of local minima. The BFI method involves two estimated parameters, the turning point test factor $(f)$ and the number of days in a nonoverlapping block $(N)$, to give a piecewise linear interpolation estimate of daily base flow. It should be noted that BFI is sometimes also used to refer to the base-flow index as a numerical parameter, which is the volume of base flow divided by the volume of streamflow for a given period. For this report, the numerical parameter will always be noted as "base-flow index," and the method will be referred to as BFI. The RDF method has two adjustable parameters, $\alpha$ and $\beta$, that are used to determine base flow ( $\alpha$ through recession analysis and $\beta$ through a backwards moving filter). In this study, the two adjustable parameters were approximated through methods developed by Raffensperger and others (2017) and Collischonn and Fan (2013).

The purpose of this report was to use the Unit Flows in Networks of Channels (UFINCH) computer application (Holtschlag, 2018), together with the measured daily streamflow at streamgages on selected rivers, to estimate streamflow in all the flowlines, that is the routes that make up a linear surface-water drainage network, of the study area (fig. 1). Then, these estimated daily streamflows were used to estimate base flows and base-flow indices for all flowlines in the major watershed. The nontidal area part of the Chesapeake Bay watershed was chosen as the example for applying these modeling tools. Streamflow values were estimated for each flowline in the National Hydrography Dataset (NHD) Plus system, version 2 (NHDPlusV2; Horizon Systems Cooperation, 2017). For large streams, computation time becomes excessive when estimating base flow for this number of flowlines. For this study, base flow and base-flow index values were estimated for each 12-digit Hydrologic Unit Code (HUC12) outlet. The analysis was performed for the 10-year interval from October 1, 2005, to October 1, 2015. The resulting data from the procedure were compiled, and for each HUC12, outlet statistics were computed including mean, maximum, minimum, standard deviation, and various percentiles of daily streamflow, and mean and standard deviation of base-flow index. Monthly mean streamflow and base-flow index were mapped and animated as a visual representation of the data. 
EXPLANATION

Flow-controlled area, Susquehanna

Nontidal area

Tidal area

Chesapeake Bay watershed boundary

Major river basin boundary

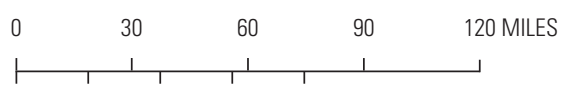

$\begin{array}{lllll}0 & 30 & 60 & 90 & 120 \text { KILOMETERS }\end{array}$

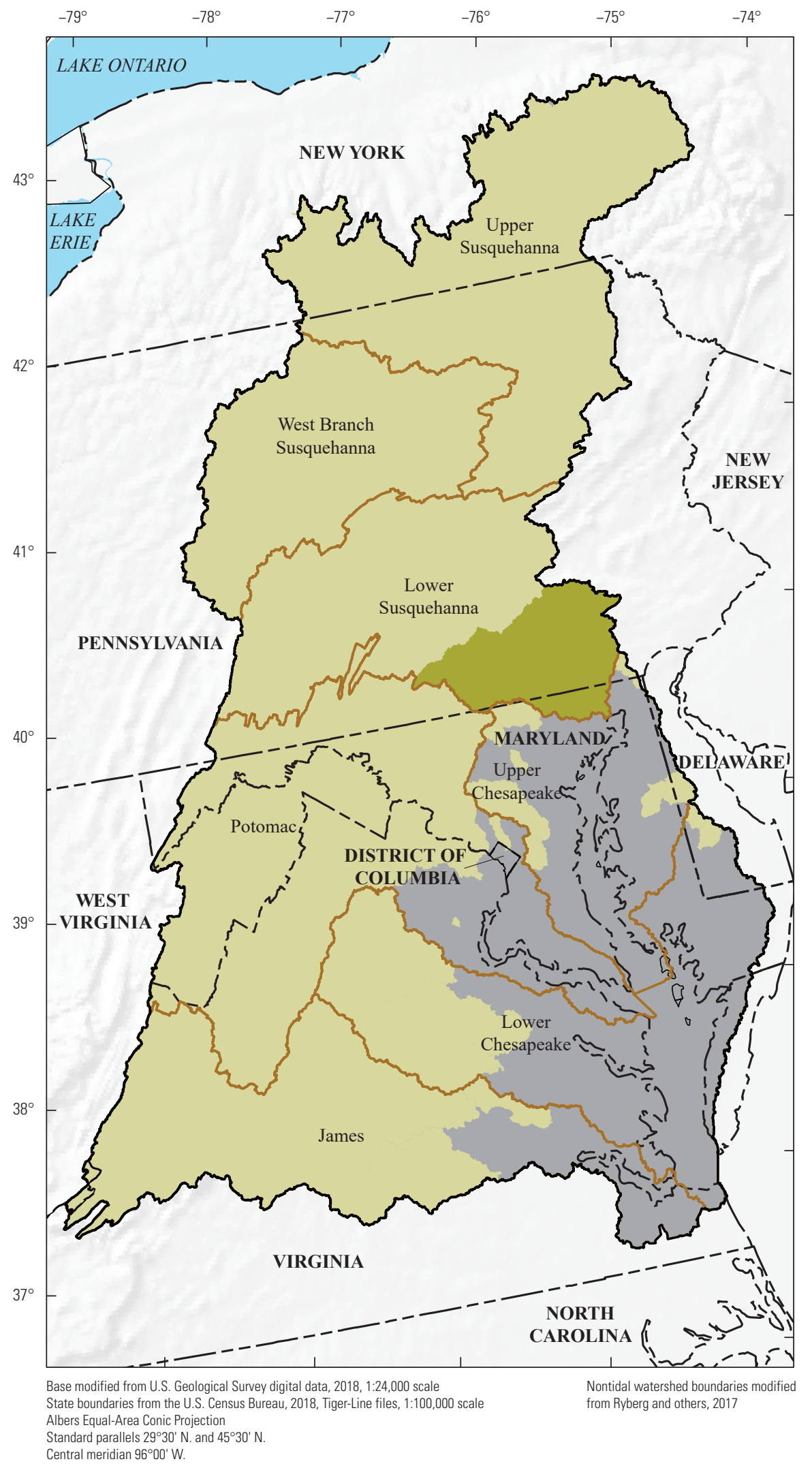

Figure 1. The Chesapeake Bay watershed. 


\section{Methods}

Using the streamflow data from 27 U.S. Geological Survey (USGS) streamgages (table 1), streamflow was modeled for each flowline throughout the nontidal area of the Chesapeake Bay watershed. From this set of streamflows, the base flow was estimated for each HUC12 outlet. To visualize the modeled data, an animation was created showing monthly streamflow and base-flow index values. Streamflow data for the 27 streamgages are available from the USGS National Water Information System (NWIS) database (U.S. Geological Survey, 2020).
Two criteria were used to decide if a streamflow record from a gage would be included. The stream site must have the appropriate period of record (October 1, 2005, to September 30,2015) and must not be tidally affected. The selected sites are shown in table 1 . The watersheds that were included in the study compose 76 percent of the total area of the Chesapeake Bay watershed (fig. 1). It should be noted that UFINCH guidelines suggest using base gages with contributing areas less than 3,000 square miles $\left(\mathrm{mi}^{2}\right)$; however, the Potomac, James, and Susquehanna watersheds exceeded this guideline. An analysis of the effect of using larger basins is included later in the report.

Table 1. Selected streamgages that were used in this report.

[Data are from the U.S. Geological Survey (USGS) National Water Information System database (USGS, 2020). N/A, not applicable]

\begin{tabular}{|c|c|c|}
\hline USGS site name & $\begin{array}{c}\text { USGS site } \\
\text { number }\end{array}$ & $\begin{array}{l}\text { Drainage area, } \\
\text { in square miles }\end{array}$ \\
\hline Pocomoke River near Willards, Maryland & 01485000 & 60.5 \\
\hline Manokin Branch near Princess Anne, Maryland & 01486000 & 4.8 \\
\hline Nanticoke River near Bridgeville, Delaware & 01487000 & 75.4 \\
\hline Marshyhope Creek near Adamsville, Delaware & 01488500 & 46.8 \\
\hline Choptank River near Greensboro, Maryland & 01491000 & 113 \\
\hline Tuckahoe Creek near Ruthsburg, Maryland & 01491500 & 85.2 \\
\hline Chesterville Branch near Crumpton, Maryland & 01493112 & 6.12 \\
\hline Morgan Creek near Kennedyville, Maryland & 01493500 & 12.7 \\
\hline Big Elk Creek at Elk Mills, Maryland & 01495000 & 51.6 \\
\hline Susquehanna River at Harrisburg, Pennsylvania & 01570500 & 24,100 \\
\hline Octoraro Creek near Richardsmere, Maryland & 01578475 & 177 \\
\hline Deer Creek near Darlington, Maryland & 01580520 & 164 \\
\hline Plumtree Run near Bel Air, Maryland & 01581752 & 2.5 \\
\hline Patapsco River at Hollofield, Maryland & 01589000 & 285 \\
\hline Patuxent River near Bowie, Maryland & 01594440 & 348 \\
\hline Western Branch at Upper Marlboro, Maryland & 01594526 & 89.7 \\
\hline Shenandoah River at Millville, West Virginia & 01636500 & 3,041 \\
\hline Potomac River near Washington, D.C., Little Falls Pump Station & 01646500 & 11,560 \\
\hline Watts Branch at Washington, D.C. & 01651800 & 3.28 \\
\hline South Fork Quantico Creek near Independent Hill, Virginia & 01658500 & 7.62 \\
\hline Rappahannock River near Fredericksburg, Virginia & 01668000 & 1,595 \\
\hline Dragon Swamp at Mascot, Virginia & 01669520 & 109 \\
\hline Pamunkey River near Hanover, Virginia & 01673000 & 1,078 \\
\hline Mattaponi River near Beulahville, Virginia & 01674500 & 603 \\
\hline James River near Richmond, Virginia1 & 02037500 & 6,753 \\
\hline Appomattox River at Matoaca, Virginia & 02041650 & 1,342 \\
\hline Chickahominy River near Providence Forge, Virginia & 02042500 & 251 \\
\hline Total area & N/A & 48,924 \\
\hline
\end{tabular}

1The James River streamflow was the sum of two gaging stations (02037500 and 02037000). The river is divided into a main channel and a canal. 
Developing the regional streamflow and base-flow animations was a four-step process: (1) estimating streamflow at ungaged streams using the UFINCH computer application (Holtschlag, 2018), (2) reformatting the UFINCH output file as an Optimal Hydrograph Separation (OHS) software package (Raffensperger and others, 2017) input file, (3) calculating base flow using two hydrograph-separation methods using the OHS software, and (4) animating the modeled streamflow and base flow.

\section{Estimating Streamflow at Ungaged Streams Using the Unit Flows in Networks of Channels Computer Application}

Streamflow analysis was performed using the UFINCH graphical user interface (GUI) (fig. 2). The UFINCH computer application can be run in the MATLAB programming environment (MathWorks, Inc., 2018) or from compiled code in a Windows Terminal. For this study, the application was run in the MATLAB environment. Before running, the UFINCH directory was setup in the proper configuration as described in the UFINCH report (Holtschlag, 2018). Once the folder structure was setup, the program was started in MATLAB from the "UFINCH/UWork" directory. Within the GUI, the following steps were taken:

1. The "02 Mid-Atlantic" hydrologic region was selected.

2. Once the hydrologic region was selected, a new figure showing the 4-digit Hydrologic Unit Code (HUC04) regions appeared (fig. 3). From this, the desired subregion was selected, such as "Lower Chesapeake."

3. The flowlines were displayed by selecting the corresponding pushbutton on the UFINCH GUI. This opened a file explorer, in which the applicable shapefile (typically the default shapefile) was selected.

4. The streamgages were displayed in the same manner as the flowlines by selecting the corresponding pushbutton control.

5. The water year was specified. When a year was entered, the streamgages that were active during that year were displayed in blue on the map, whereas those that were inactive were displayed in grey.

6 . The base streamgage, the most downstream point in the network, was selected by clicking on the triangle displayed on the map. The name and number, as well as drainage area, location, and Common Identifiers number (ComID), of the flowline on which the selected gage was located was displayed in the main UFINCH GUI.
7. Once the desired streamgage was selected, the "Select Base Streamgage" button was selected to highlight the stream network upstream from the base streamgage.

8. The streamflow data record for the selected base streamgage was read. The "Read 15-min Flows" button was selected, and a file explorer window appeared. If a file with the ".dFloMea" extension for the streamgage with the selected dates had already been downloaded, it was selected; otherwise, the "cancel" button was selected, and a prompt to download a new file opened. After accepting the prompt, a browser window opened, and the user was prompted for start and end dates for the requested data. Daily flows for the specified period are automatically retrieved and discretized to 15-minute intervals. Note that 15 -minute intervals are used in UFINCH simulations because the minimum time of travel through a flowline is about 15 minutes. The UFINCH computer application calculates travel time from all flowlines to the base streamgage. The start date of the simulation and the start date of the streamflow data must be separated by a number of days at least as great as the longest travel time in the network. For this reason, the start date of the data period was specified to be 6 days before the desired start of the simulation.

9. Travel times were computed throughout the network based on mean flow velocities and flowline lengths documented in the National Hydrography Dataset (NHDPlusV2; Horizon Systems Cooperation, 2017). UFINCH gave an option to select a proportion for mean stream velocities between 1 and 10 . For this study, the selected proportion was always 2.5 as suggested by Holtschlag (2018). After the proportion was specified, the "Calculate Travel Times" button was selected. The travel times for each flowline were computed as the NHDPlusV2 flowline length divided by the mean flow velocity and displayed in the MATLAB command window.

10. The date range of the simulation was specified in the start and end date text boxes, and the "Simulate Unit Flows at All Flowlines" button was selected. This process uses a large amount of system memory for large streamflow networks and needed to be split into multiple shorter date ranges for the two largest flow networks, gages 01646500 (Potomac River near Washington, D.C., Little Falls Pump Station; drainage area 11,560 $\mathrm{mi}^{2}$ ) and 01570500 (Susquehanna River at Harrisburg, Pennsylvania; drainage area 24,100 $\mathrm{mi}^{2}$ ).

11. Once the simulation was complete, unit (15-minute) streamflows were averaged to daily streamflows by selecting the "Aggregate Unit" button in the GUI. 


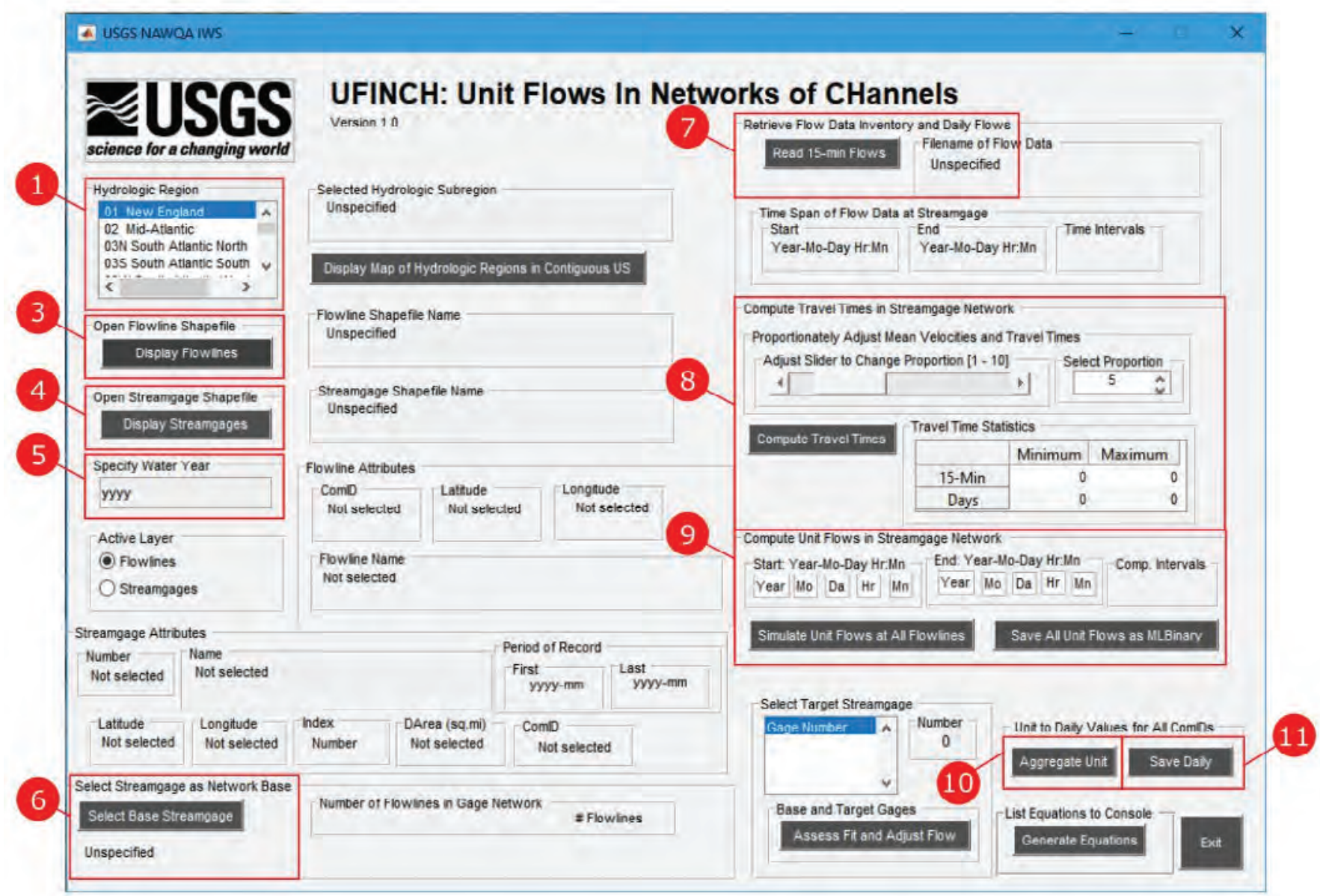

Figure 2. A reproduction of the Unit Flows in Networks of Channels graphical user interface (Holtschlag, 2018). The numbers in the red discs correspond to text in a numbered list found in the "Estimating Streamflow at Ungaged Streams Using the Unit Flows in Networks of Channels Computer Application" section. Number 2 was intentionally omitted in this figure.

12. The streamflows were saved by selecting the "Save Daily Flows" button. UFINCH saved the streamflows as a file under the name "networkXXXXXXXX.txt" where XXXXXXXX was the gage number. The output file gave the flowline ComID as the first row, the date as the first column, and the streamflow for each flowline and date in the corresponding row/column.

The GUI provided an option to select individual streamgages to view a comparison between modeled and measured flows at the streamgage. There also was an option to automatically adjust the modeled streamflows so that the error between modeled flows and measured streamflows at the streamgage could be minimized. In this study, no streamflows were adjusted. This was because the adjustment modifies streamflows differently at each gage to minimize errors, and it was desired that modeling was uniform for the large-scale simulation.

The Potomac and Susquehanna basins were analyzed differently than the other basins. To account for the terrain disparity in the Potomac watershed, the UFINCH analysis was performed on the entire basin and then on the Shenandoah subbasin. The modeled values from the Shenandoah analysis were then used to replace the values for the same region in the Potomac analysis. Because of the size of the Susquehanna basin, UFINCH analysis required more system memory than available, so the simulation was split into five 2-year segments. Only the part of the Susquehanna River upstream from the gage at Harrisburg, Pa., was analyzed because of the series of reservoirs downstream from this point. 


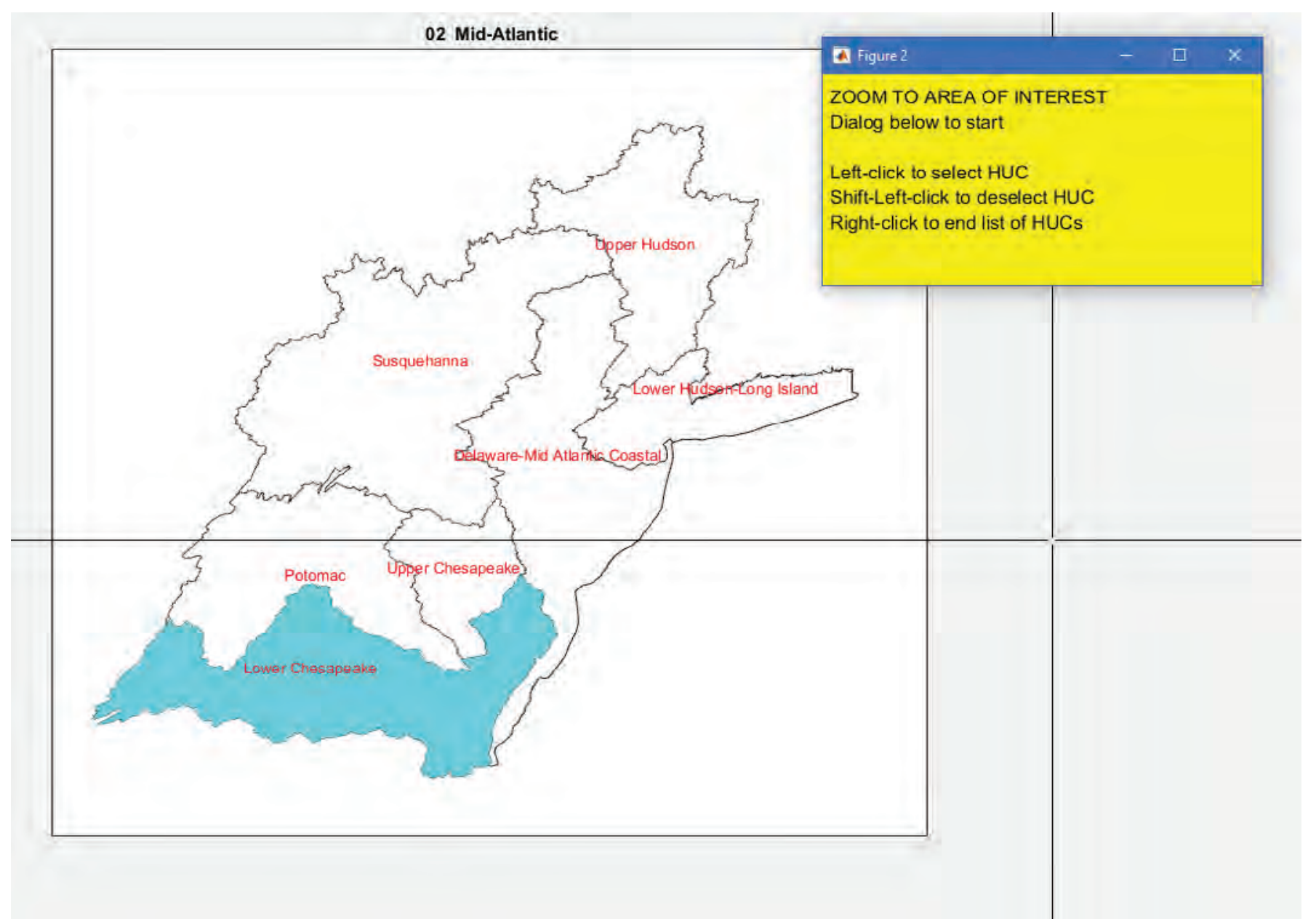

Figure 3. The interactive map contained within the Unit Flows in Networks of Channels graphical user interface.

\section{Reformatting the Unit Flows in Networks of Channels Computer Application Output File as an Optimal Hydrograph Separation Software Package Input File}

The next step of the process was to reformat the streamflow file from UFINCH so that it could be used by the OHS software (Raffensperger and others, 2017). Because the OHS software has a long runtime for networks with many sites, base flow was computed at the flowline at the outlet of each of the HUC12 basins (U.S. Geological Survey and U.S. Department of Agriculture, Natural Resources Conservation Service, 2013). The UFINCH estimated streamflow out of each HUC12 was used for base-flow analysis. To determine HUC12 streamflows, the NHDPlusV2 digital stream hydrography was analyzed to locate the endpoints for each flowline. To determine which flowlines were HUC12 outlets, the locations of the start and endpoints of each flowline were compared. If a flowline started in a different HUC12 from which it ended, it meant the flowline crossed a HUC12 boundary and, therefore, was an outlet of the basin of its upstream endpoint. Only streamflows for outlet flowlines were saved, and flows from the set of flowlines that originated in the same HUC12 were aggregated. The exception to this is at a base gage, at which the daily streamflow was kept for the individual flowline on which the base gage was located. This is because the base gage was typically in the middle of a HUC12, therefore not representing its total outflow. The daily streamflows for each HUC12 were saved as an individual file, named "QXXXXXXXXXXXX_Daily.csv," which contained three columns: HUC12, date (mm/dd/yyyy), and streamflow (Buffington and others, 2020). A file named "sitelist.txt," containing a single column with each HUC12 number that was analyzed, also was saved. This process was performed by creating a set of MATLAB functions. The first function (outlets.m) is used to read the prepared list of ComIDs of flowlines that leave each HUC12 and the associated HUC12. The second function (Ufinch_out_read.m) is used to read the streamflow file from UFINCH. The third function (Ufinch_convert.m) takes these two datasets and then computes and saves mean daily streamflow for each HUC12. 
Finally, a fourth function (streamNetwork.m) is used to call each of these functions in order, as well as starts the base flow program, so that there are less steps for the user. For further reference, the four functions are included in the data release (Buffington and others, 2020).

\section{Calculating Base Flow Using Two Hydrograph-Separation Methods Using the Optimal Hydrograph Separation Software Package}

The next step was to calculate the base flow at each HUC12 outlet by using the BFI and RDF methods developed by Wahl and Wahl (1995) and by Eckhardt (2005), respectively, with the parameter estimation (ParE) method developed by Collischonn and Fan (2013), which are incorporated into the OHS software (Raffensperger and others, 2017). To run the OHS software, the file structure was properly configured as described in the data release (Buffington and others, 2020). Within the OHS software, the "bfi_sin_ cos.m" function was run individually for each flow network after the reformatting and filtering functions were run. After running the base-flow function, five file types were produced:

1. Streamflow, base flow, and base-flow index produced by the RDF-ParE methods.

2. Streamflow, base flow, and base-flow index produced by the BFI method.

3. The same streamflow and base-flow values from files 1 and 2 given in a single file.

4. Base-flow estimation parameters.

5. Streamflow and base flow from each method listed for every HUC12 in the flow network.

The first three files were produced for each HUC12, whereas the last two were produced for the whole network. The four files that give flow values each have a format of one row per day per HUC12, with columns giving the flow values. The set of five files from each simulation were combined into one large file giving the daily stream and base flows at each HUC12; this single aggregate file (daily.csv) is included in Buffington and others (2020). After the calculation of base flow, the full set of files listed above was placed in a new folder because the MATLAB function will overwrite any files that have the same name as a file that MATLAB writes in another run of the function.
Statistics were computed for each HUC12, including mean streamflow; standard deviation of streamflow; minimum streamflow; maximum streamflow; 1st, 5th, 10th, 20th, 25th, 50th, 75th, 80th, 90th, 95th, and 99th streamflow percentiles; and 10 -year base-flow index for each of the two base-flow separation methods. These summary statistics for each HUC12 are included in Buffington and others (2020).

\section{Animating the Modeled Streamflow and Base Flow}

After estimating streamflow and base flow, an animation was created to visualize the streamflow and base-flow index. The daily streamflow data were aggregated to monthly data for the animation. Monthly base-flow index values were calculated by summing the daily base flow and daily streamflow for each month, then dividing cumulative base flow by cumulative streamflow. A file (monthlyflows.csv) containing the HUC12, month, streamflow, base flow from the BFI and RDF-ParE methods, and base-flow index values from these two methods is included in Buffington and others (2020).

Once the dataset was aggregated to monthly values, the streamflow animation was made in ArcGIS. The NHDPlusV2 flowline shapefile was imported. A table of Chesapeake Bay NHDPlusV2 ComIDs with their associated HUC12s was added. This file was then joined to NHD flowline so that only the desired flowlines would be displayed, and each flowline had a HUC12 associated with it. A dissolve was performed on the NHDPlusV2 flowline by HUC12 so that the flowlines within a HUC12 would have the same flow data and display. This also reduced the graphical power needed to display such a detailed shapefile. The layer created from the dissolve function was then exported to a new personal geodatabase. The "monthlyflows.csv" file was added to the map and exported to the same geodatabase. The "Make Query Table" command was used to create a one-to-many join between the flowlines and monthly flows. The query expression entered was "[NHDFlowlines_dissolve.HUC12] $=$ [monthlyflows. HUC12]." No key fields were selected, but all fields were checked in the "Select Fields" box. After this step, each HUC12 was represented by a set of flowlines and had a set of 120 monthly flows. To animate the data, "Enable time on this layer" was selected in the layer properties. The time slider was selected in the toolbar, and animation settings were selected.

To animate the base-flow index, the same steps were taken, however, the original shapefile was the HUC12_CB file rather than NHDPlus V2 flowline (Buffington and others, 2020). 


\section{Analyzing Accuracy and Consistency}

Accuracy and consistency of results were measured using two parameters: the percent error $(P E)$ and the Nash-Sutcliffe $(N S)$ efficiency coefficient. $P E$ was calculated using the formula:

$$
P E=\frac{\text { estimated }- \text { measured }}{\text { measured }} \times 100 \%
$$

The NS efficiency coefficient (Nash and Sutcliffe, 1970) was used as a measure of accuracy for streamflow estimated and consistency of base-flow estimates. This metric compares model predictions to the mean of observed data and is calculated as:

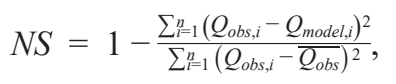

where

$$
\begin{gathered}
Q_{o b s, i} \quad \begin{array}{l}
\text { is the measured streamflow value at time } i, \\
Q_{\text {model, } i}
\end{array} \quad \begin{array}{l}
\text { is the UFINCH-generated streamflow value at } \\
\text { time } i, \text { and }
\end{array} \\
\overline{Q_{o b s}} \quad \text { is the mean measured streamflow value. }
\end{gathered}
$$

Based on this equation, the values of NS range from $-\infty$ to 1 , with a value of $N S$ less than zero indicating that the mean value is a better predictor of streamflow than the model, whereas a value near 1 indicates a good fit between the modeled and measured data.

\section{Results and Discussion}

\section{Statistics of Streamflow and Base Flow for Nontidal Areas of the Chesapeake Bay Watershed}

Daily and monthly modeled estimates of streamflow and base flow, calculated by two hydrograph-separation methods, were estimated at the outlet point of each HUC12 in the study area, representing most of the nontidal area of the Chesapeake Bay watershed. Hydrologic statistics for streamflows and base flows (mean, standard deviation, minimum, and maximum, as well as 1st, 5th, 10th, 25th, 50th, 75th, 90th, 95th, and 99th percentiles) also were calculated. The results of the study are provided in the data release (Buffington and others, 2020).

\section{Accuracy of Streamflow Estimates}

To assess the effect of using larger watersheds than recommended in the UFINCH documentation (less than
3,000 $\mathrm{mi}^{2}$; Holtschlag, 2018), the daily streamflows during the period of record at USGS streamgages within the watershed of the Potomac base gage (USGS gage 01646500, Potomac River at Washington D.C., Little Falls Pump Station) were compared to the corresponding daily streamflow values estimated by UFINCH (figs. 4-9).

To compare the estimates to measured values, the $P E$ and $N S$ were calculated. These parameters were each plotted against (1) the flow distance between the comparison gages and the base gage and (2) the drainage area ratio of the comparison gages to the base gage. Streamflow estimates for gages upstream from USGS gage 01636500 (Shenandoah River at Millville, West Virginia) were plotted twice, once where the base gage was gage 01646500 and once where the base gage was 01636500 . This allows for a comparison between the analysis of the Potomac watershed and a subset that follows the UFINCH guidelines, with a drainage area of 3,041 $\mathrm{mi}^{2}$.

As shown in figures 4-7, there is little relation between UFINCH accuracy and the distance between the two gages or the drainage area ratio. However, estimates made when using gage 01636500 (Shenandoah River at Millville, West Virginia) were marginally more accurate than those made when using gage 01646500 (Potomac River at Washington, D.C.), as evidenced by lower percent errors and higher NS efficiency coefficients (fig. 9). This suggests that the accuracy of estimates in a UFINCH analysis does not substantially degrade with distance from the base gage or drainage area ratio (fig. 4-7), but there is substantial uncertainty in the estimate of daily streamflow values at all scales (figs. 8 and 9). This makes regional-scale analyses difficult because there are parts of large watersheds that have drainage areas larger than $3,000 \mathrm{mi}^{2}$ and, therefore, violate the UFINCH guidelines.

To further assess the accuracy of the UFINCH streamflow estimation in more detail, six USGS streamgages were selected to compare measured streamflows to modeled streamflows. Since modeled flows were recorded at HUC12 outlets, the six sites were selected so that streamgages were as near an outlet as possible. Three first-order basins (those whose streamflow only comes from runoff within the basin) and three second- or higher-order basins (those that have a streamflow input from another basin) were used to examine the accuracy of the model results. The selected gages and characteristics are shown in table 2.

The NS efficiency coefficients were computed for the logarithm of the daily and monthly mean streamflows at each of the six selected sites (table 3). To visualize the fit between the modeled and measured data, the logarithms of the two streamflow datasets were plotted against each other, shown in figures 10 and 11. 

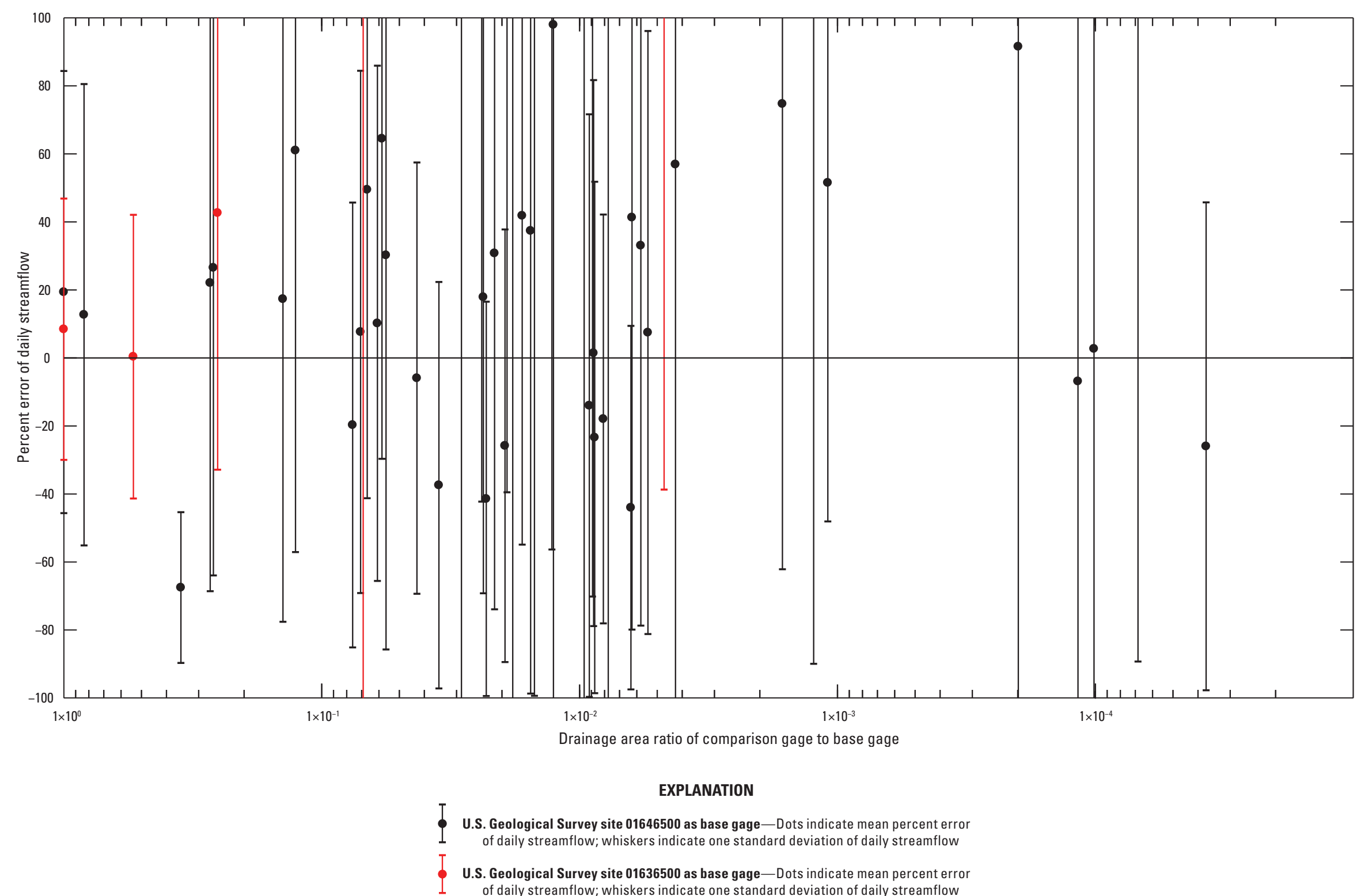

Figure 4. Percent error of daily streamflows (October 1,2005 , to September 30,2015$)$ with respect to the drainage area ratio between the comparison gages and base gage. 


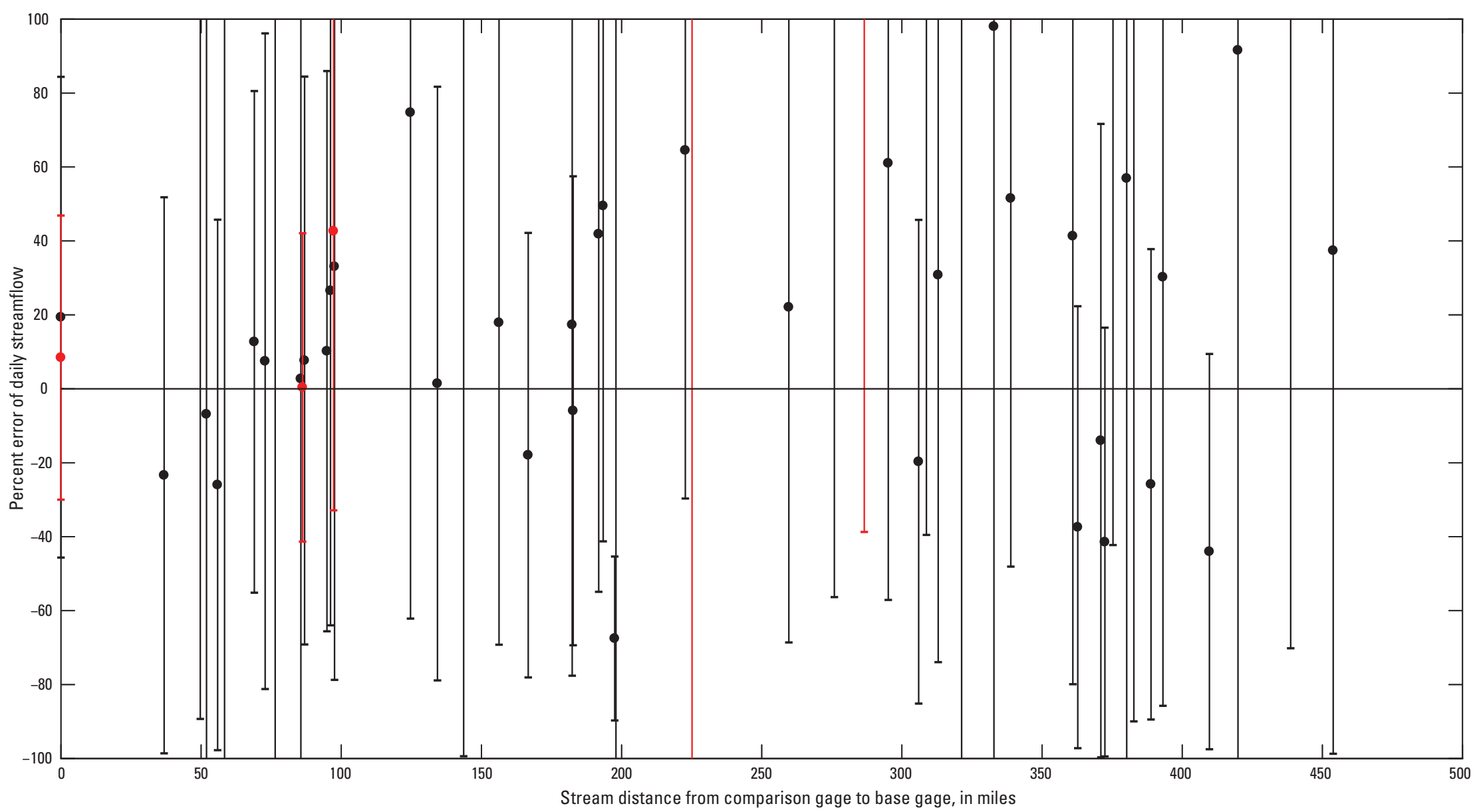

\section{EXPLANATION} U.S. Geological Survey site 01646500 as base gage-Dots indicate mean percent error
of daily streamflow; whiskers indicate one standard deviation of daily streamflow

U.S. Geological Survey site 01636500 as base gage-Dots indicate mean percent error of daily streamflow; whiskers indicate one standard deviation of daily streamflow

Figure 5. Percent error of daily streamflows (0ctober 1, 2005, to September 30, 2015) with respect to the flow distance from the comparison gages and base gage. 


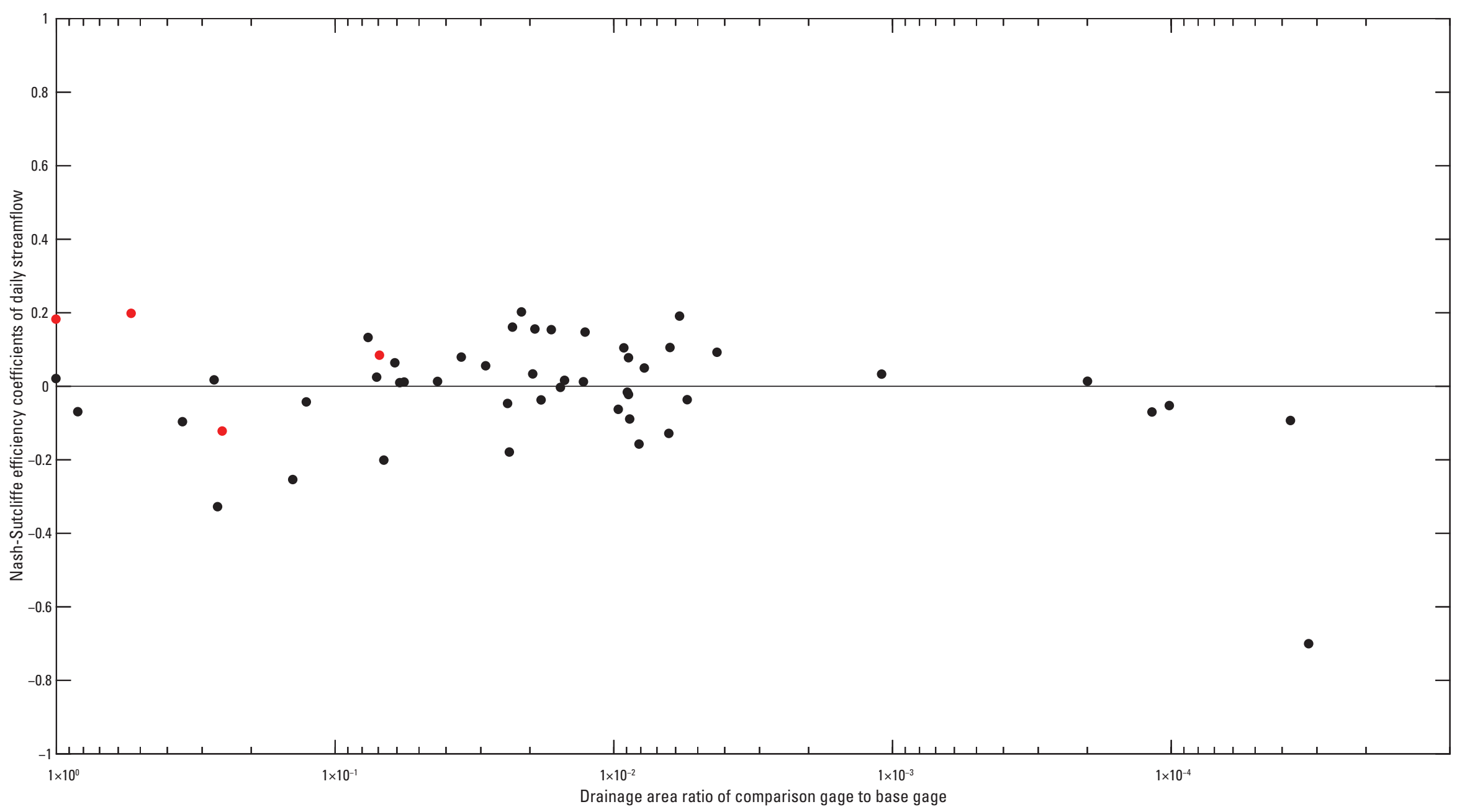

EXPLANATION

- U.S. Geological Survey site 01646500 as base gage

- U.S. Geological Survey site 01636500 as base gage

Figure 6. The Nash-Sutcliffe efficiency coefficients for daily streamflow (0ctober 1, 2005, to September 30, 2015) with respect to the drainage area ratio between the comparison gages and base gage. 


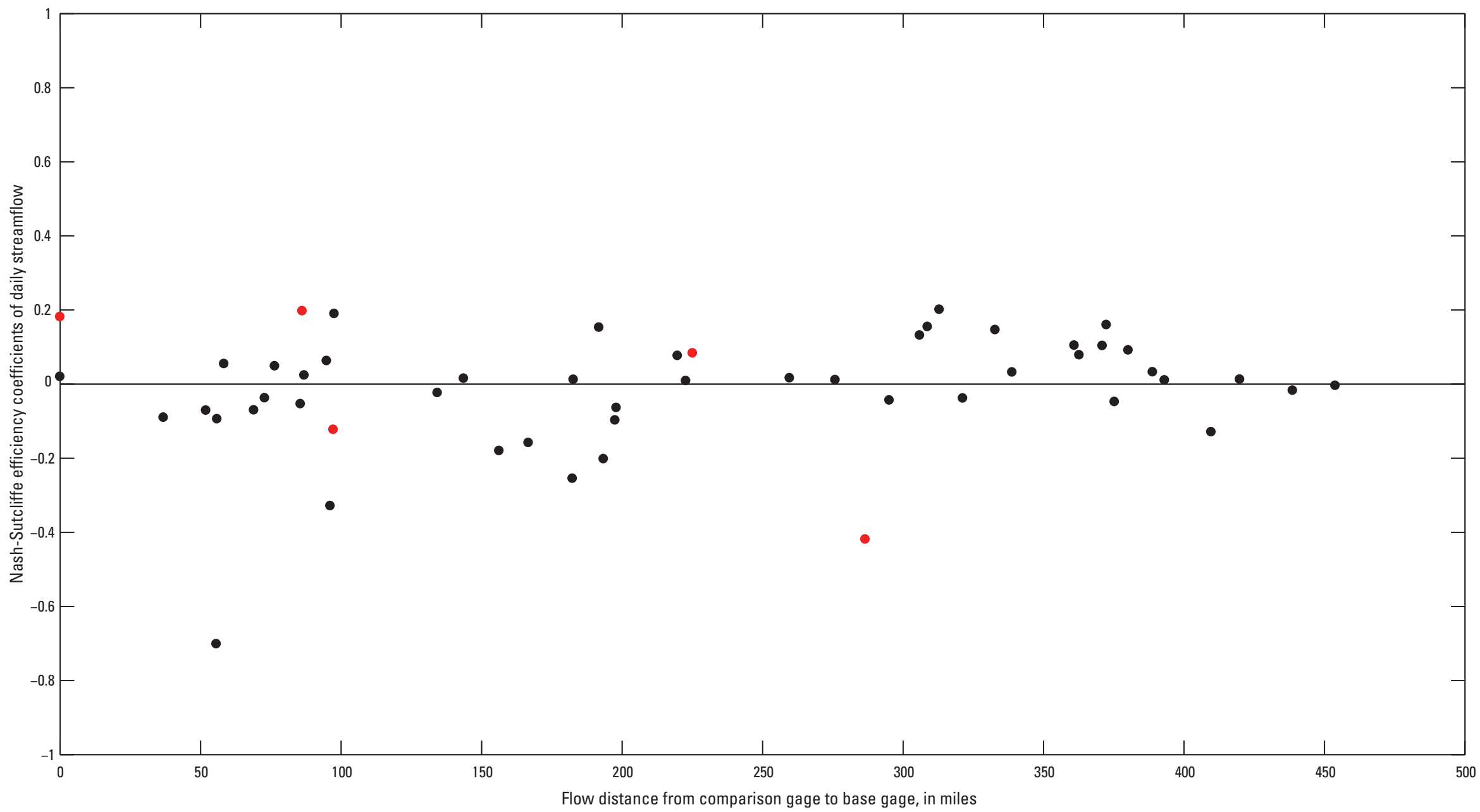

\section{EXPLANATION}

- U.S. Geological Survey site 01646500 as base gage

U.S. Geological Survey site 01636500 as base gage

Figure 7. The Nash-Sutcliffe efficiency coefficients for daily streamflow (October 1, 2005, to September 30, 2015) with respect to the flow distance from the comparison gages to the base gage. 


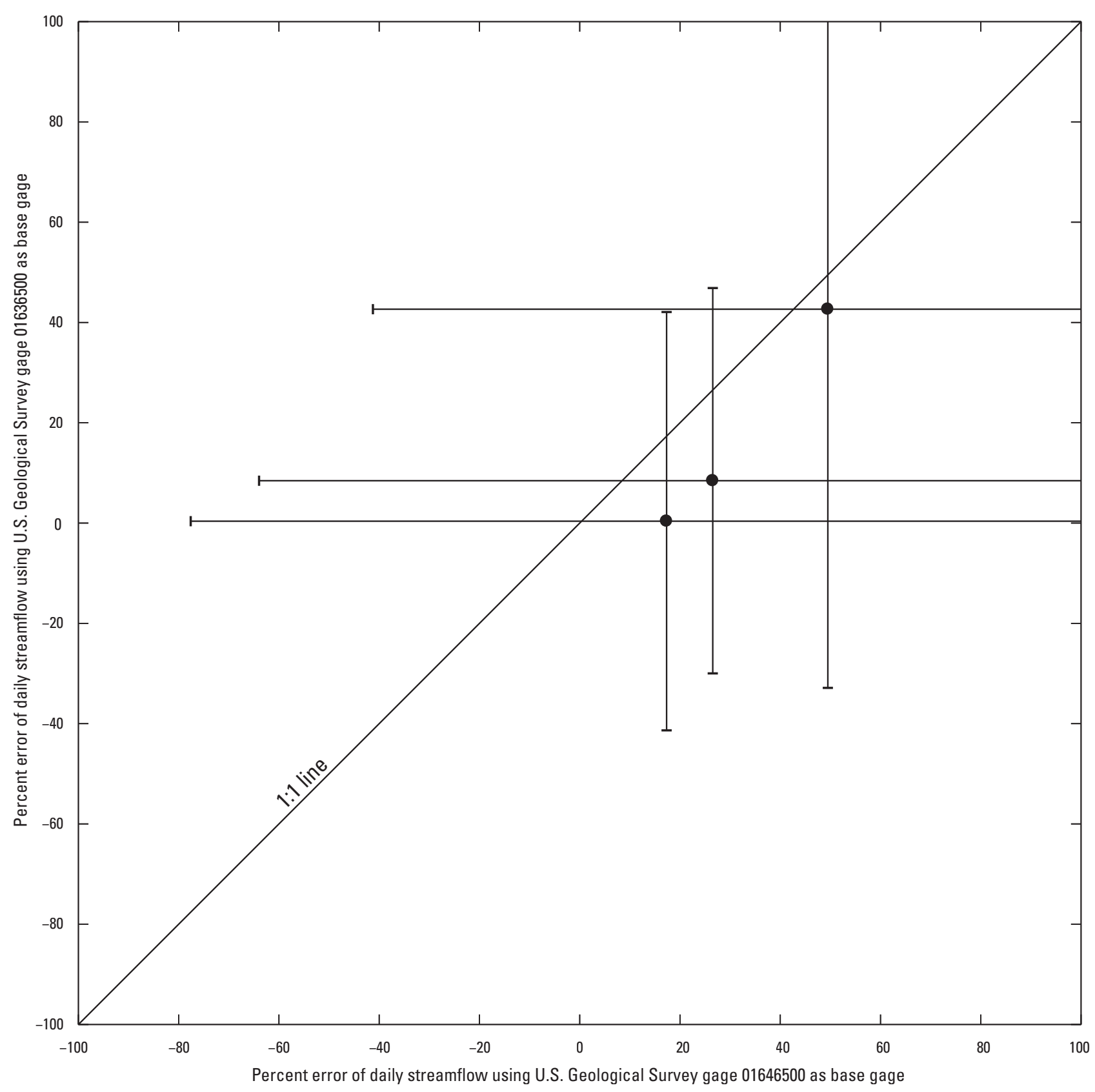

Figure 8. Percent error of daily streamflows (October 1, 2005 to September 30, 2015) using the Potomac River at Washington, D.C. (U.S. Geological Survey [USGS] gage 01646500), as the base gage compared to using Shenandoah River at Millville, West Virginia (USGS gage 01636500), as the base gage. 


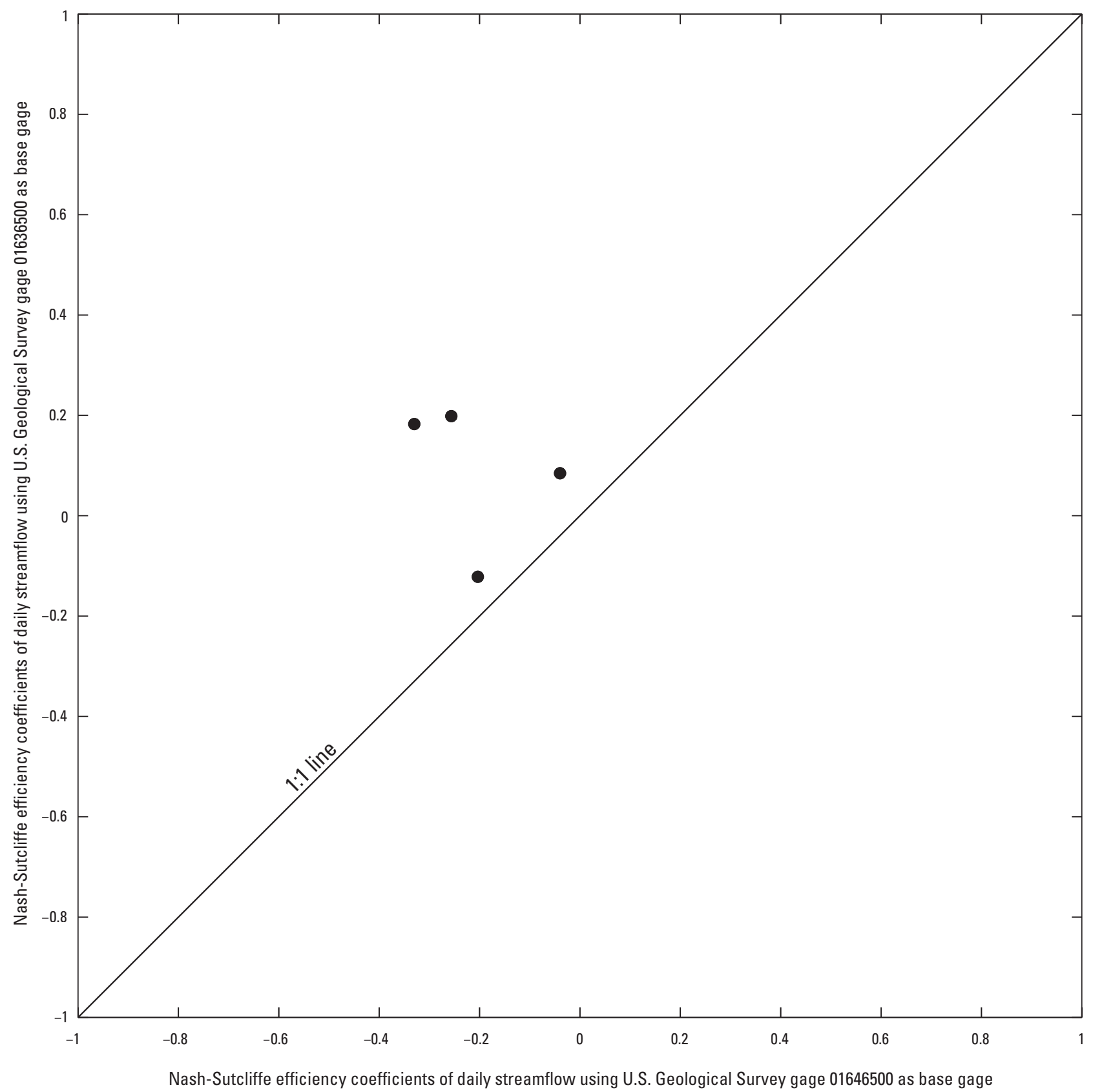

Figure 9. The Nash-Sutcliffe efficiency coefficients for daily streamflow (October 1, 2005, to September 30, 2015) using Potomac River at Washington, D.C. (U.S. Geological Survey [USGS] gage 01646500), as the base gage compared to using Shenandoah River at Millville, West Virginia (USGS gage 01636500), as the base gage. 
Table 2. Selected sites for assessment of the accuracy of the modeled daily and monthly streamflow compared to the measured values and comparison of the two hydrograph-separation methods.

[Site names and numbers are from the U.S. Geological Survey (USGS) National Water Information System database (USGS, 2020). HUC12, 12-digit Hydrologic Unit Code; >, greater than]

\begin{tabular}{lcccc}
\hline \multicolumn{1}{c}{ USGS site name } & $\begin{array}{c}\text { USGS site } \\
\text { number }\end{array}$ & HUC12 & $\begin{array}{c}\text { Stream } \\
\text { order }\end{array}$ & $\begin{array}{c}\text { Drainage area, } \\
\text { in square miles }\end{array}$ \\
\hline Battle Run near Laurel Mills, Virginia & 01662800 & 20801030303 & 1 & 25.9 \\
Kerrs Creek near Lexington, Virginia & 02022500 & 20802020302 & 1 & 35.1 \\
Linville Creek at Broadway, Virginia & 01632082 & 20700060302 & 1 & 45.8 \\
North Fork of the Shenandoah River near Strasburg, Virginia & 01634000 & 20700060503 & $>1$ & 770 \\
Sideling Hill Creek near Bellegrove, Maryland & 01610155 & 20700030305 & $>1$ & 102 \\
Conodoguinet Creek near Hogestown, Pennsylvania & 01570000 & 20503050406 & $>1$ & 470 \\
\hline
\end{tabular}

Table 3. Summary of the assessment of the accuracy of the modeled daily and monthly streamflow compared to the measured values and the degree of the agreement between the daily and monthly base-flow index values calculated by two hydrograph-separation methods.

[Site names and numbers are from the U.S. Geological Survey (USGS) National Water Information System database (USGS, 2020)]

\begin{tabular}{|c|c|c|c|c|c|}
\hline \multirow{3}{*}{ USGS site name } & \multirow{3}{*}{$\begin{array}{c}\text { USGS } \\
\text { site } \\
\text { number }\end{array}$} & \multicolumn{4}{|c|}{ Nash-Sutcliffe efficiency coefficient } \\
\hline & & \multicolumn{2}{|c|}{$\begin{array}{c}\text { Measured and } \\
\text { modeled streamflow }\end{array}$} & \multicolumn{2}{|c|}{$\begin{array}{l}\text { Base flow index from } \\
\text { hydrograph separatior }\end{array}$} \\
\hline & & Daily & Monthly & Daily & Monthly \\
\hline Battle Run near Laurel Mills, Virginia & 01662800 & 0.66 & 0.79 & 0.63 & 0.72 \\
\hline Kerrs Creek near Lexington, Virginia & 02022500 & 0.34 & 0.72 & 0.51 & 0.57 \\
\hline Linville Creek at Broadway, Virginia & 01632082 & 0.14 & 0.48 & 0.40 & 0.47 \\
\hline North Fork of the Shenandoah River near Strasburg, Virginia & 01634000 & 0.49 & 0.86 & 0.61 & 0.62 \\
\hline Sideling Hill Creek near Bellegrove, Maryland & 01610155 & 0.16 & 0.37 & 0.44 & 0.52 \\
\hline Conodoguinet Creek near Hogestown, Pennsylvania & 01570000 & 0.0004 & 0.39 & 0.22 & 0.093 \\
\hline
\end{tabular}

The UFINCH model did not produce a systematic bias for the over or underestimation of streamflows. For five of the six selected gages, the points are well distributed around the 1:1 lines (figs. $11 B, C$, and $D$ ). However, at Sideling Hill Creek near Bellegrove, Maryland, the modeled streamflows systematically overestimated the lowest measured streamflows, especially when the streamflows were below 10 cubic feet per second. Compared to figures $10 \mathrm{~A}$, $B$, and $C$, the streamflows in Sideling Hill Creek were uncharacteristically low for the size of the watershed compared to the other three streams with smaller drainage areas. This may indicate that UFINCH can be a poor predictor of streamflows at extremely low-flow conditions, or Sideling Creek was just an anomaly. It should be noted that the selected gages were not located at exactly the outlets of their respective HUC12s. This means there are small areas of the HUC12s that contribute water to the modeled streamflow that are not included in the measured streamflow values. This could contribute to the overestimate of streamflows at many of the selected gages.
Based on the NS efficiency coefficients at the selected gages, UFINCH does not seem to perform substantially differently for the first- or higher-ordered basins. Both basin types gave some high and some low NS efficiency coefficients. This lack of bias towards basin type is important because both basin types are present in regional areas like the Chesapeake Bay watershed.

The NS efficiency coefficients were always lower in the daily compared to the monthly analysis of accuracy of the modeled streamflows (table 3). In some cases, the NS efficiency coefficients for daily streamflows were close to zero, meaning the modeled values were not an improvement over simply using the mean streamflow for the 10-year period. However, for the monthly values, the NS efficiency coefficients were substantially higher, in the range of 0.37 to 0.86 . This indicates that the UFINCH application was a good model for predicting general streamflow patterns, rather than predictions of daily streamflow values for this analysis. 
Battle Run near Laurel Mills, Virginia (01662800)

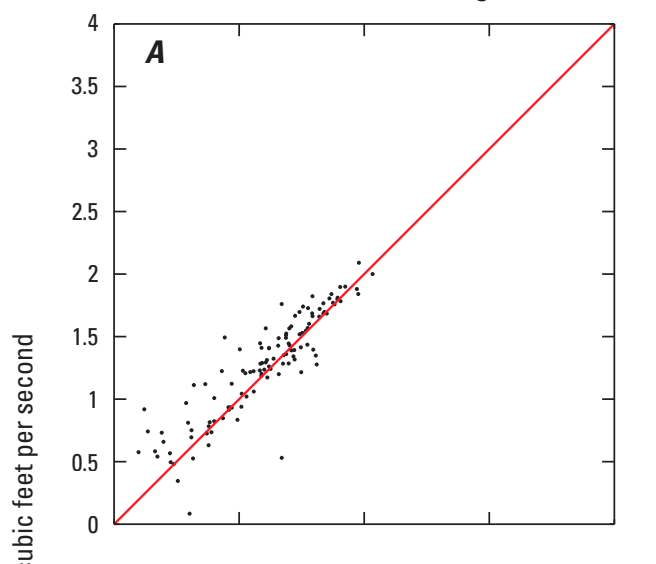

North Fork of the Shenandoah River near Strasburg, Virginia (01634000)

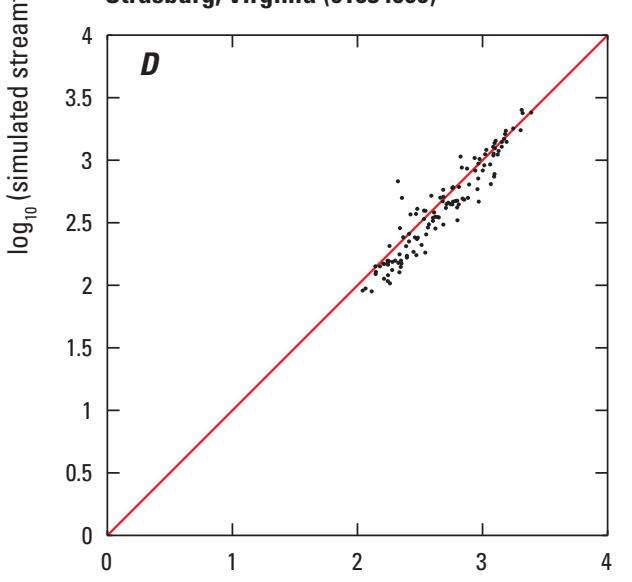

Kerrs Creek near Lexington, Virginia (02022500)

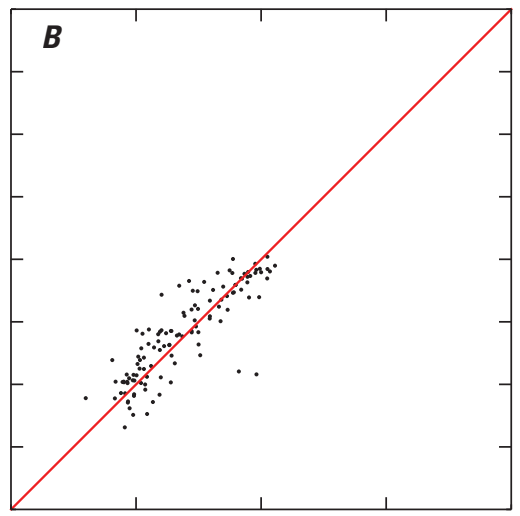

Sideling Hill Creek near Bellegrove, Maryland (01610155)

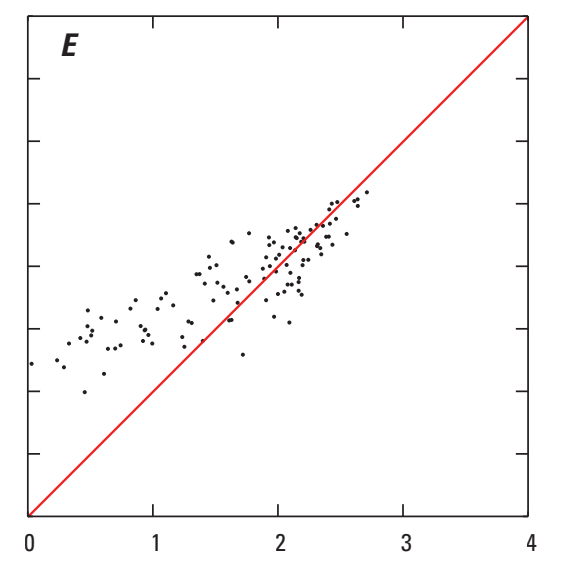

Linville Creek at Broadway, Virginia (01632082)

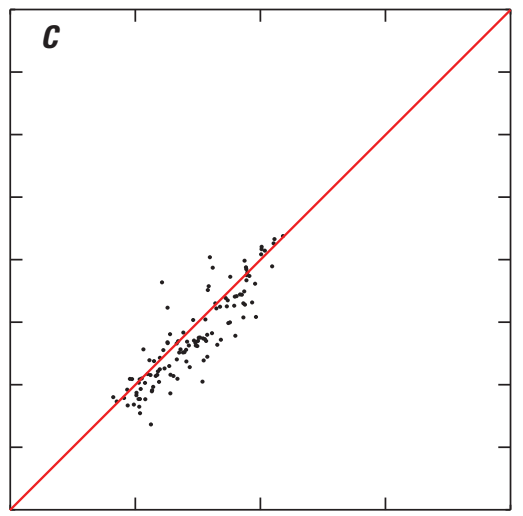

Conodoguinet Creek near Hogestown Pennsylvania (01570000)

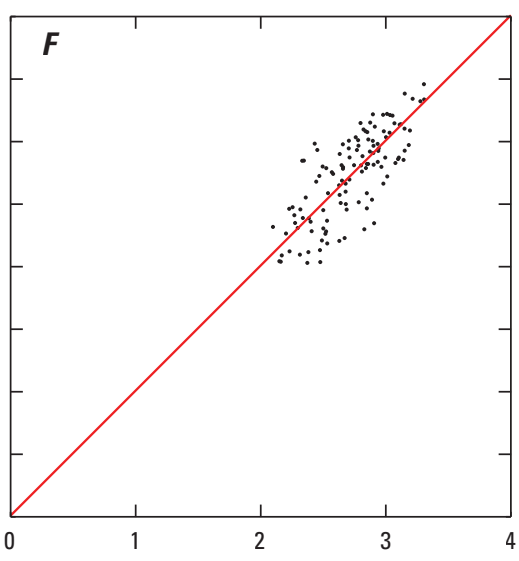

$\log _{10}$ (measured streamflow), in cubic feet per second

\title{
EXPLANATION
}

\author{
1:1 line
}

Figure 10. The relation between modeled and measured monthly streamflows for the 10-year period from 0ctober 1, 2005, to September 30, 2015, for the six sites listed in table 2. A, Battle Run near Laurel Mills, Virginia (U.S. Geological Survey [USGS] gage 01662800). B, Kerrs Creek near Lexington, Virginia (USGS gage 02022500). C, Linville Creek at Broadway, Virginia (USGS gage 01632082). $D$, North Fork of the Shenandoah River near Strasburg, Virginia (USGS gage 01634000). E, Sideling Hill Creek near Bellegrove, Maryland (USGS gage 01610155). F, Conodoguinet Creek near Hogestown, Pennsylvania (USGS gage 01570000). 


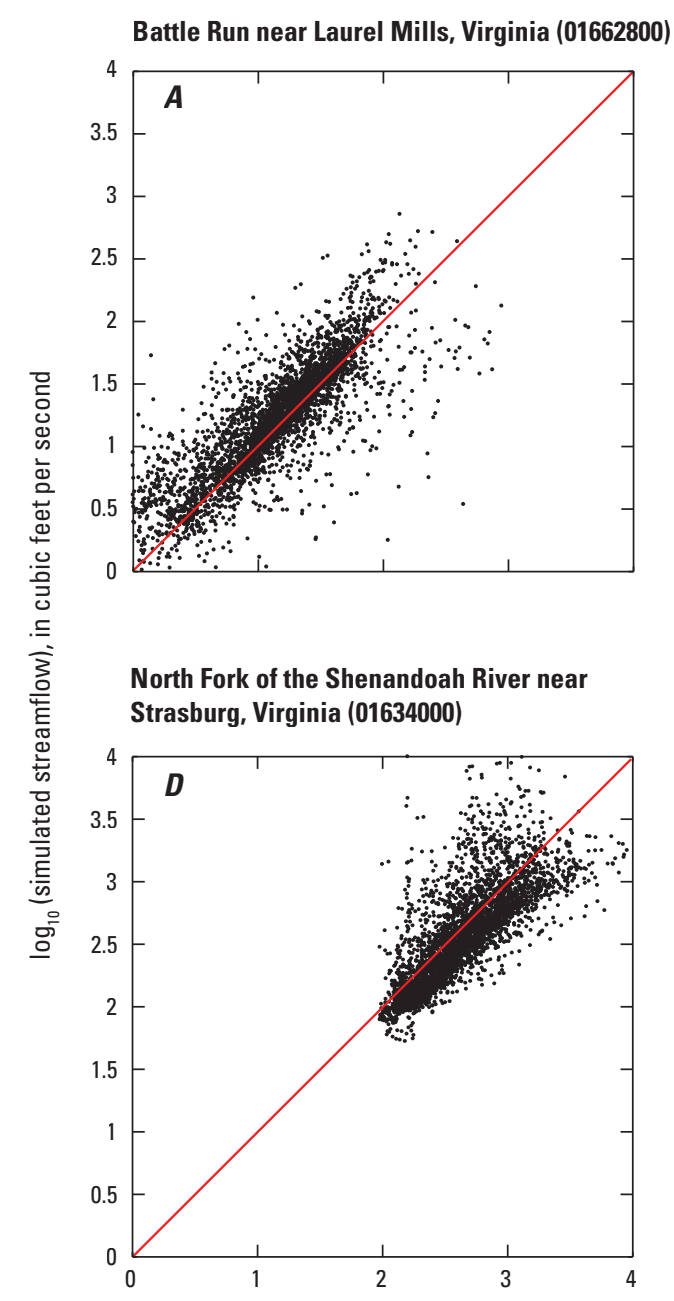

Kerrs Creek near Lexington, Virginia (02022500)

Linville Creek at Broadway, Virginia (01632082)
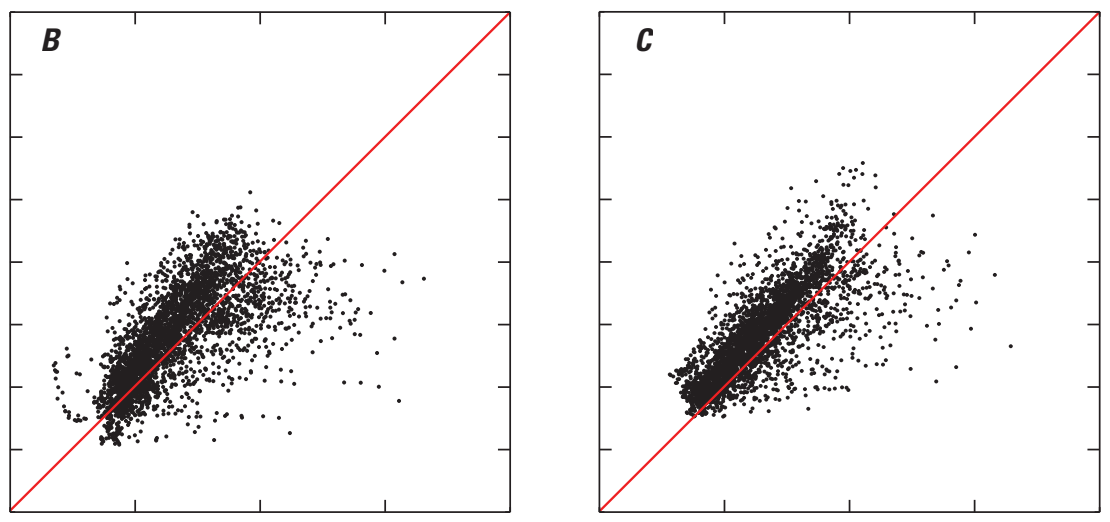

Sideling Hill Creek near Bellegrove,

Maryland (01610155)

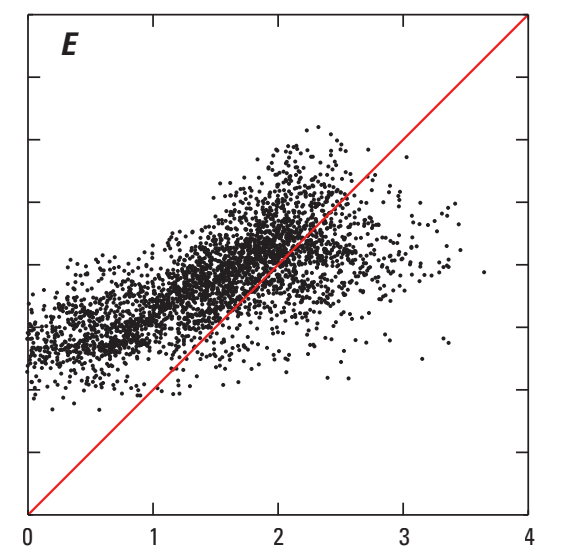

Conodoguinet Creek near Hogestown,

Pennsylvania (01570000)

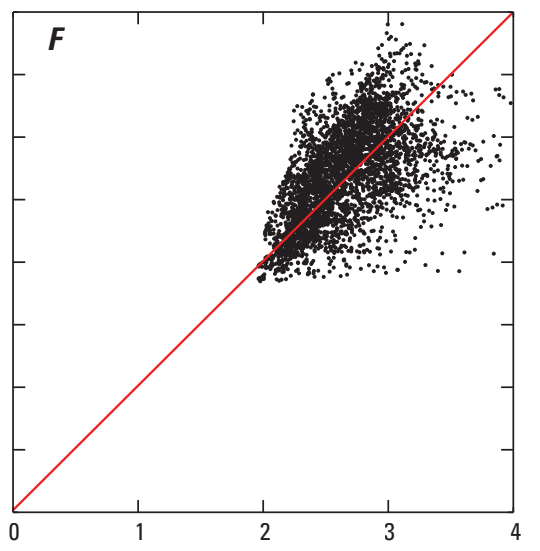

$\log _{10}$ (measured streamflow), in cubic feet per second

\section{EXPLANATION}

Figure 11. The relation between modeled and measured daily streamflows for the 10 -year period from 0ctober 1, 2005, to September 30 2015, for the six sites listed in table 2. A, Battle Run near Laurel Mills, Virginia (U.S. Geological Survey [USGS] gage 01662800). B, Kerrs Creek near Lexington, Virginia (USGS gage 02022500). C, Linville Creek at Broadway, Virginia (USGS gage 01632082). D, North Fork of the Shenandoah River near Strasburg, Virginia (USGS gage 01634000). E, Sideling Hill Creek near Bellegrove, Maryland (USGS gage 01610155). F, Conodoguinet Creek near Hogestown, Pennsylvania (USGS gage 01570000). 


\section{Summary of Monthly Streamflow and Base-Flow Data for Selected Sites}

To visualize the monthly patterns in streamflow and base flow, monthly box plots for 10 years of streamflow and estimated base-flow data for the six sites in table 2, are shown in figure 12. All six sites followed similar annual streamflow trends with peak streamflow in the spring (March or April) and lower streamflows in the fall. Late spring and summer streamflows in the upper quartile and upper outlier regions regularly exceeded those of March and April at many sites. These sporadic high-flow events are the result of large storms that did not occur every year.

Base flow followed a similar pattern but with smaller changes throughout the year. In many cases from November through April, the median base flow was only about one-half of the median streamflow; therefore, the base-flow index was around 0.5 . But, during the drier summer months, streamflow and base flow were nearly equal because during times with low precipitation, the source of streamflow is thought to be almost completely groundwater.

Although the annual patterns in the modeled data were mostly similar between sites, 2 months were anomalous. Conodoguinet Creek near Hogestown, Pa., had base-flow values during September and October of 2011 that were much higher than the other months (shown as outlier values in fig. 12D). However, this site had the worst correlation between modeled and observed streamflow at the daily level, the second-worst correlation at the monthly level, and the worst correlation between base-flow index estimates, so it is difficult to draw firm conclusions from these data.

\section{Comparison of Base-Flow Estimates}

Estimates of base flow were made by two hydrograph-separation methods: BFI and RDF. The monthly and daily value datasets provided by the two hydrograph-separation methods were compared to each other to assess their degree of agreement (figs. 13 and 14; table 3). The daily base-low index was computed for each day by dividing the daily base flow by the daily streamflow. For the monthly base-flow index, the total base flow in a month was divided by the total streamflow of the same month. The
NS efficiency coefficients were calculated as a measure of agreement between the methods.

The strong degree of agreement of the monthly BFI estimated by the two hydrograph-separation methods is shown in figure 13. Most of the data points cluster evenly around the 1:1 line. For the monthly values, the NS efficiency coefficients ranged from 0.52 to 0.72 , except for at Conodoguinet Creek, which had NS efficiency coefficients as much as only 0.09 . There was generally better agreement of BFI between the two hydrograph-separation methods for the monthly values compared to the daily values (table 3 ).

\section{Animations of Streamflow and Base Flow}

To illustrate the temporal and spatial variability of streamflow and base flow, four animations (access at https://doi.org/10.3133/sir20205055) were created from the monthly data: Susquehanna watershed monthly mean streamflow, Susquehanna monthly base-flow index, nontidal Chesapeake Bay watershed outside of the Susquehanna watershed monthly mean streamflow, and nontidal Chesapeake Bay watershed outside of the Susquehanna watershed monthly base-flow index. The base-flow index values in the animations were determined by the RDF-ParE method.

In figures 15-18, the NHDPlusV2 flowlines are used to represent the streamflow and base-flow indices for each HUC12. The line thickness represents the different streamflow values and line color represents different base-flow index values.

For streamflow, the largest flows occurred in the spring months because of snowmelt and precipitation and lower flows in the summer months. Summer and fall streamflows sometimes had localized higher flows for a month or two at a time, likely because of large storms. The base-flow index was highly variable, spatially and temporally, with most values between 0.4 and 1.0. During the spring, these base-flow indices were lower when most streamflow consisted of runoff. The spatial variation in base flow was high in these months because the amount of snow and timing of snowmelt is highly dependent on elevation. During the summer, base-flow indices were typically higher, with most values closer to 1.0 than in the spring. Spatial variation here was likely because of 

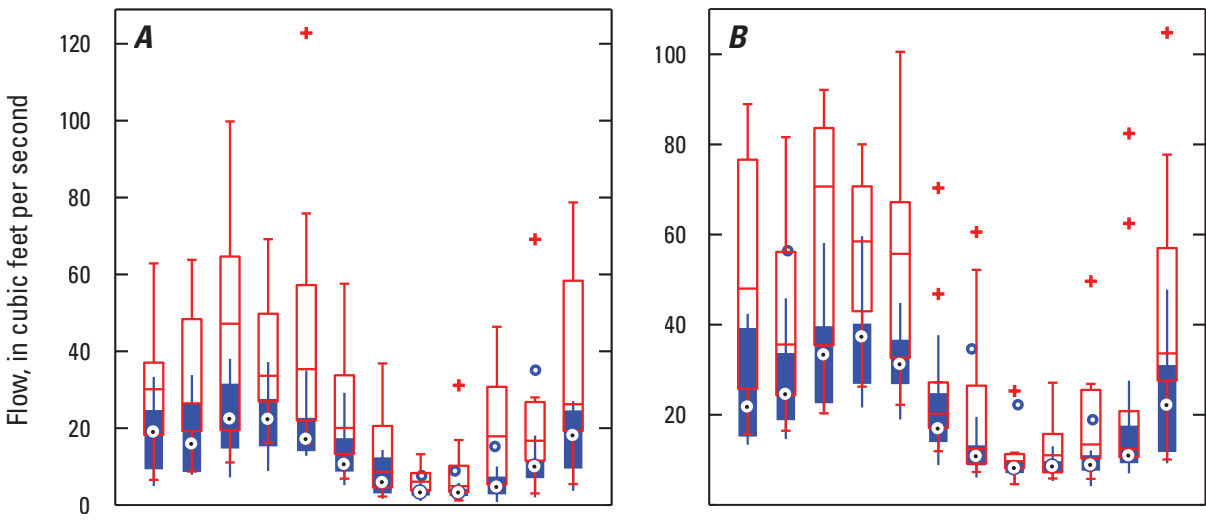

North Fork of the Shenandoah River nea Strasburg, Virginia (01634000)

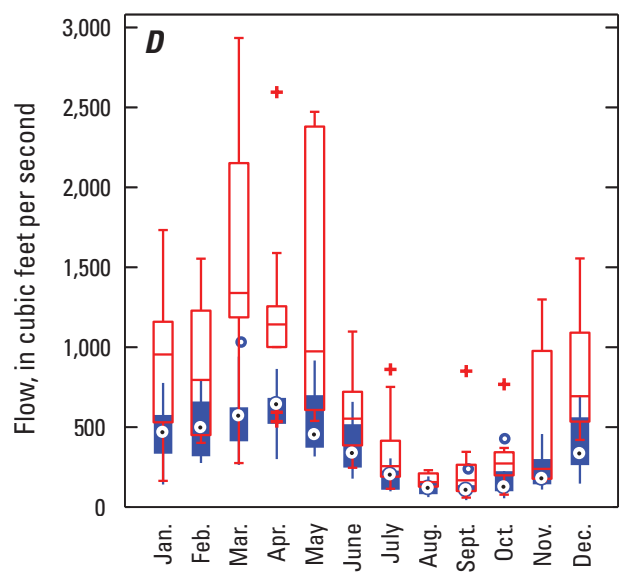
Maryland (01610155)

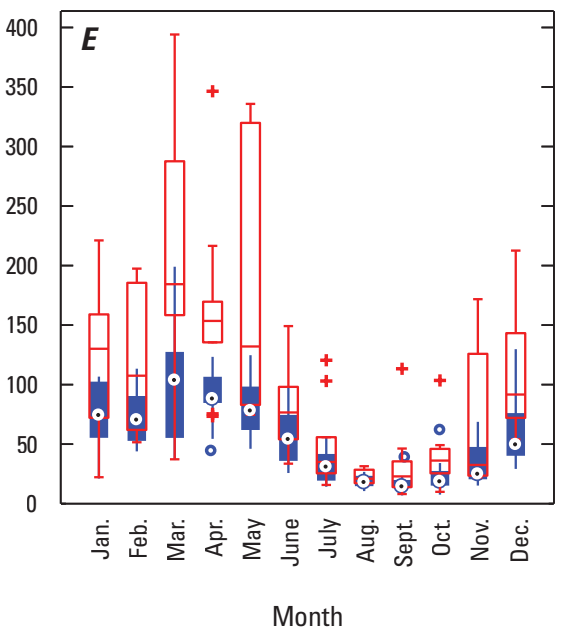

Sideling Hill Creek near Bellegrove,

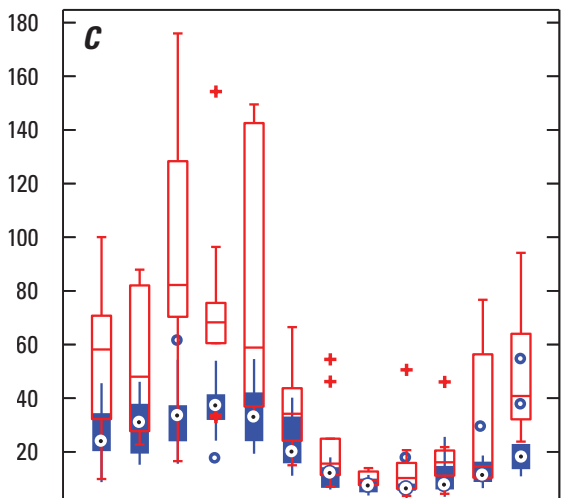

Conodoguinet Creek near Hogestown, Pennsylvania (01570000)

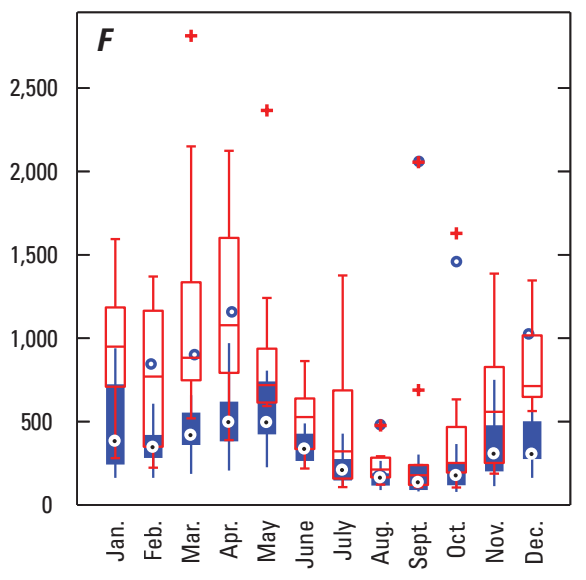

\section{EXPLANATION}

Statistical summary for streamflow

99.65th percentile
75th percentile
50th percentile (median)
25th percentile
0.35 th percentile
$+\quad$ Outlier value

\section{Statistical summary for estimated} base flow

99.65th percentile

75th percentile

50th percentile (median)

25th percentile

0.35 th percentile

- Outlier value

Figure 12. Ten years (October 1, 2005, to October 1, 2015) of monthly streamflow and estimated base flow (based on the base-flow index method developed by Wahl and Wahl, 1995) for the four of the sites listed in table 2. A, Battle Run near Laurel Mills, Virginia (U.S. Geological Survey [USGS] gage 01662800). B, Kerrs Creek near Lexington, Virginia (USGS gage 02022500). C, Linville Creek at Broadway, Virginia (USGS gage 01632082). D, North Fork of the Shenandoah River near Strasburg, Virginia (USGS gage 01634000). E, Sideling Hill Creek near Bellegrove, Maryland (USGS gage 01610155). F, Conodoguinet Creek near Hogestown, Pennsylvania (USGS gage 01570000). 

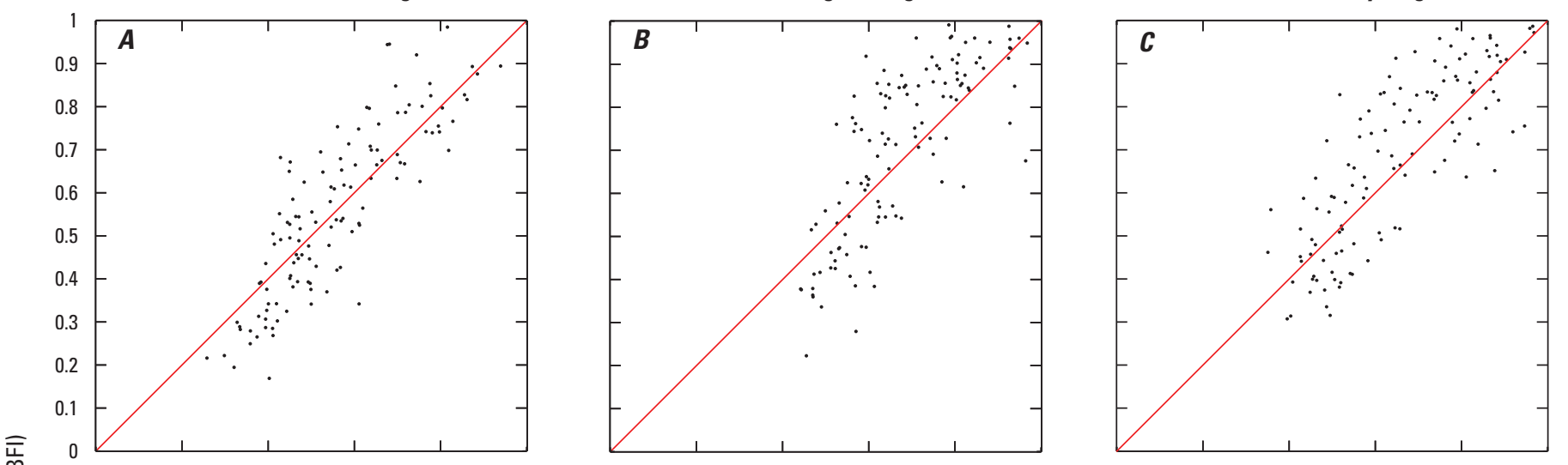

\section{North Fork of the Shenandoah River near} Strasburg, Virginia (01634000)

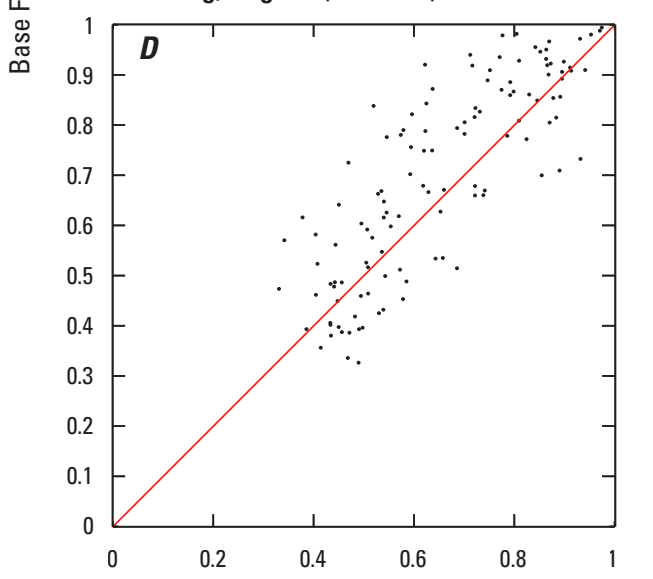

\section{Sideling Hill Creek near Bellegrove,} Maryland (01610155)

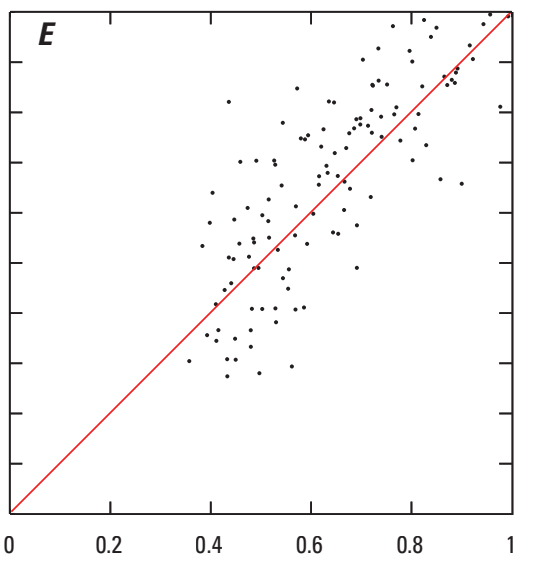

Conodoguinet Creek near Hogestown, Pennsylvania (01570000)

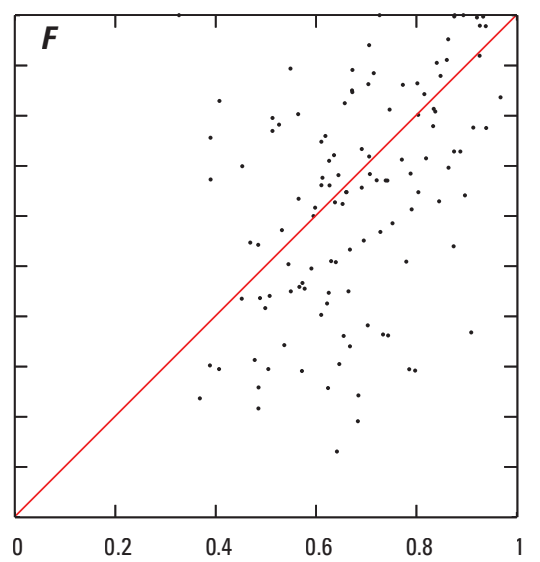

Base Flow Index (recursive digital filter [Eckhardt, 2005] and parameter estimate methods [Collischonn and Fann, 2013])

\section{EXPLANATION}

\section{1:1 line}

Figure 13. The relation between monthly base-flow index values estimated by two hydrograph-separation methods for the 10-year period from October 1, 2005, to September 30, 2015, for the six sites listed in table 2. A, Battle Run near Laurel Mills, Virginia (U.S. Geological Survey [USGS] gage 01662800). B, Kerrs Creek near Lexington, Virginia (USGS gage 02022500). C, Linville Creek at Broadway, Virginia (USGS gage 01632082). D, North Fork of the Shenandoah River near Strasburg, Virginia (USGS gage 01634000). E, Sideling Hill Creek near Bellegrove, Maryland (USGS gage 01610155). F, Conodoguinet Creek near Hogestown, Pennsylvania (USGS gage 01570000). 


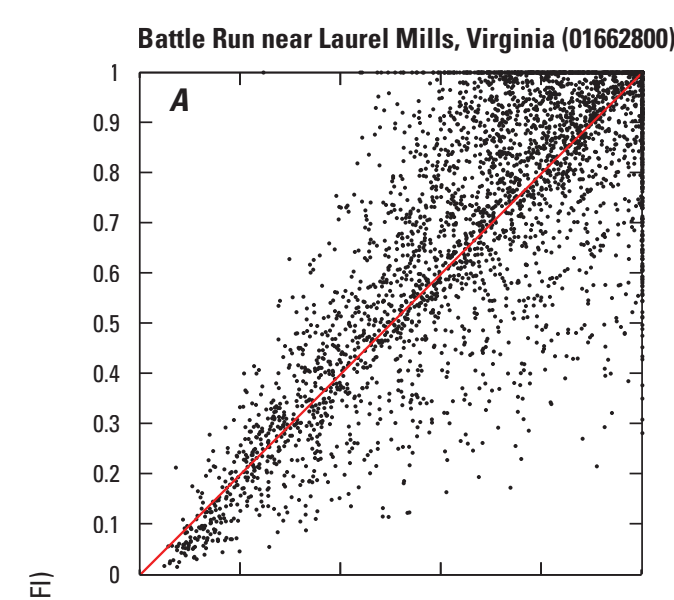

Kerrs Creek near Lexington, Virginia (02022500)

Linville Creek at Broadway, Virginia (01632082)
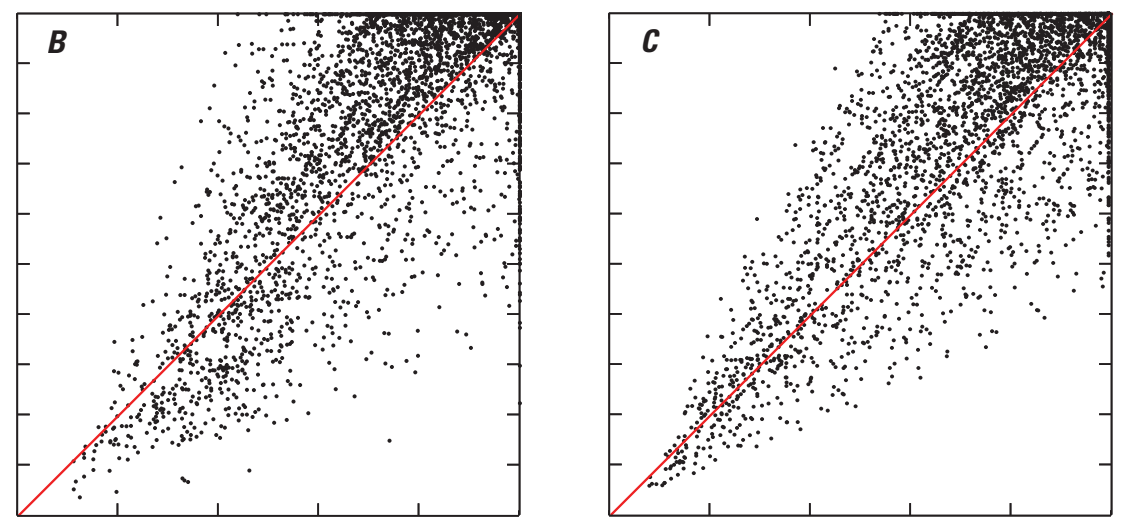

North Fork of the Shenandoah River near Strasburg, Virginia (01634000)

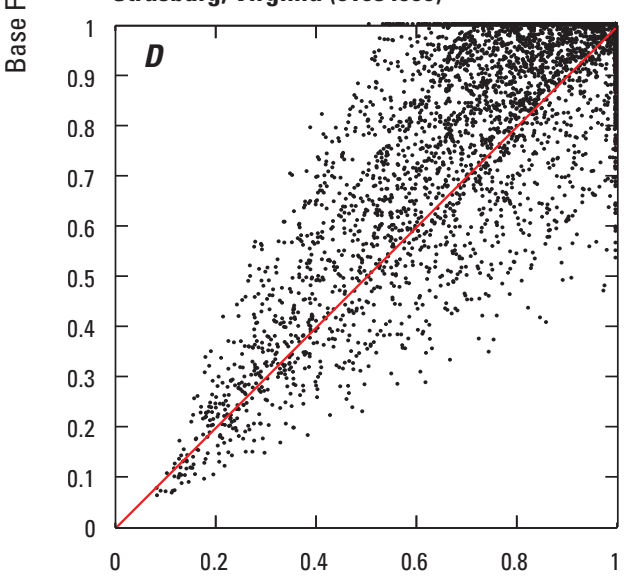

Sideling Hill Creek near Bellegrove, Maryland (01610155)

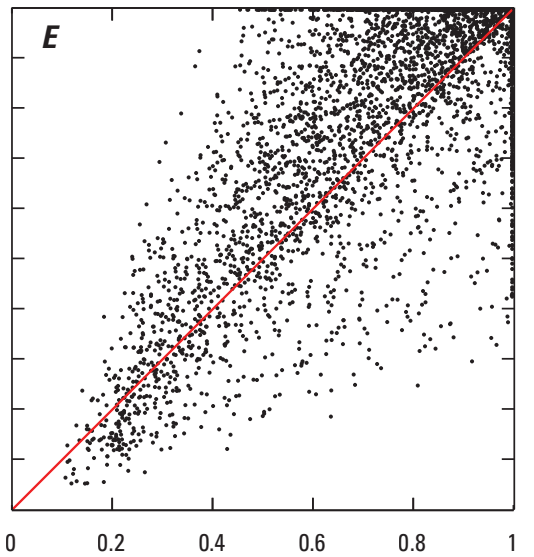

Conodoguinet Creek near Hogestown, Pennsylvania (01570000)

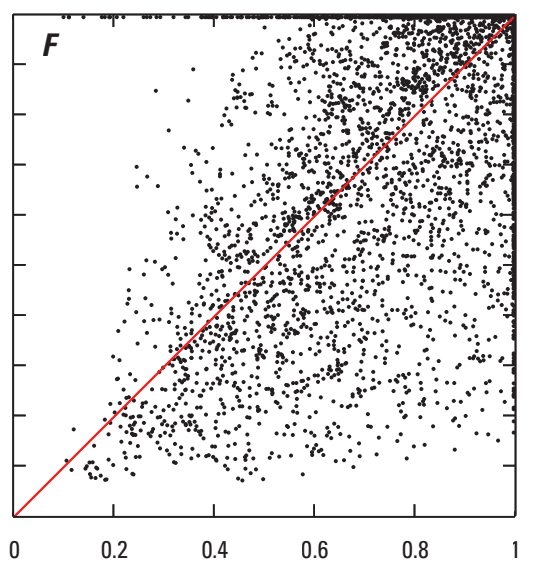

Base Flow Index (recursive digital filter [Eckhardt, 2005] and parameter estimate methods [Collischonn and Fann, 2013])

\section{EXPLANATION}

\section{1:1 line}

Figure 14. The relation between daily base-flow index values estimated by two hydrograph-separation methods for the 10-year period from October 1, 2005, to September 30, 2015, for the six sites listed in table 2. A, Battle Run near Laurel Mills, Virginia (U.S. Geological Survey [USGS] gage 01662800). B, Kerrs Creek near Lexington, Virginia (USGS gage 02022500). C, Linville Creek at Broadway, Virginia (USGS gage 01632082). D, North Fork of the Shenandoah River near Strasburg, Virginia (USGS gage 01634000). E, Sideling Hill Creek near Bellegrove, Maryland (USGS gage 01610155). F, Conodoguinet Creek near Hogestown, Pennsylvania (USGS gage 01570000). 


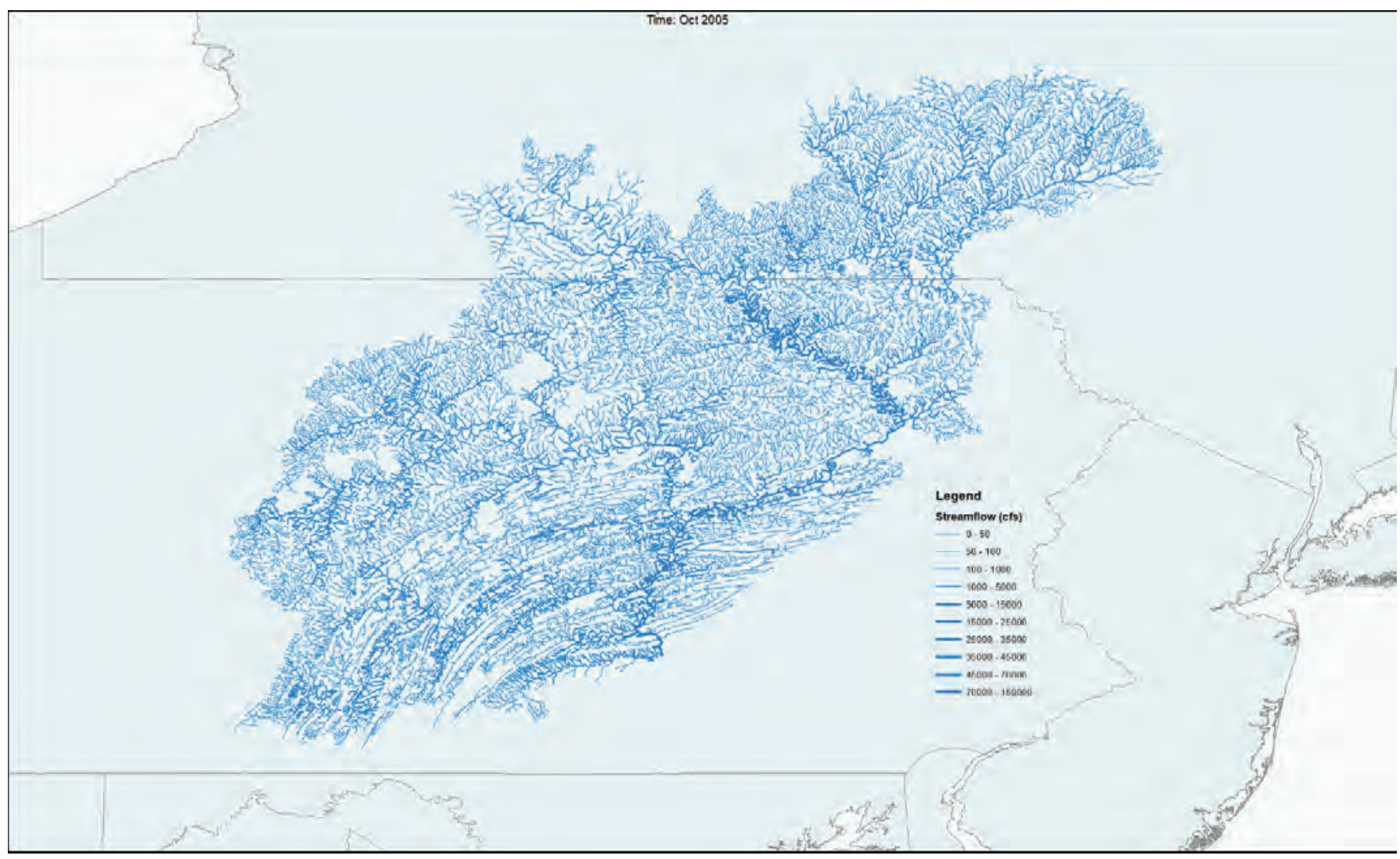

Figure 15. The first frame of the monthly mean streamflow animation for the watershed of the Susquehanna River, upstream from Harrisburg, Pennsylvania. View animation at https://doi.org/10.3133/sir20205055. 


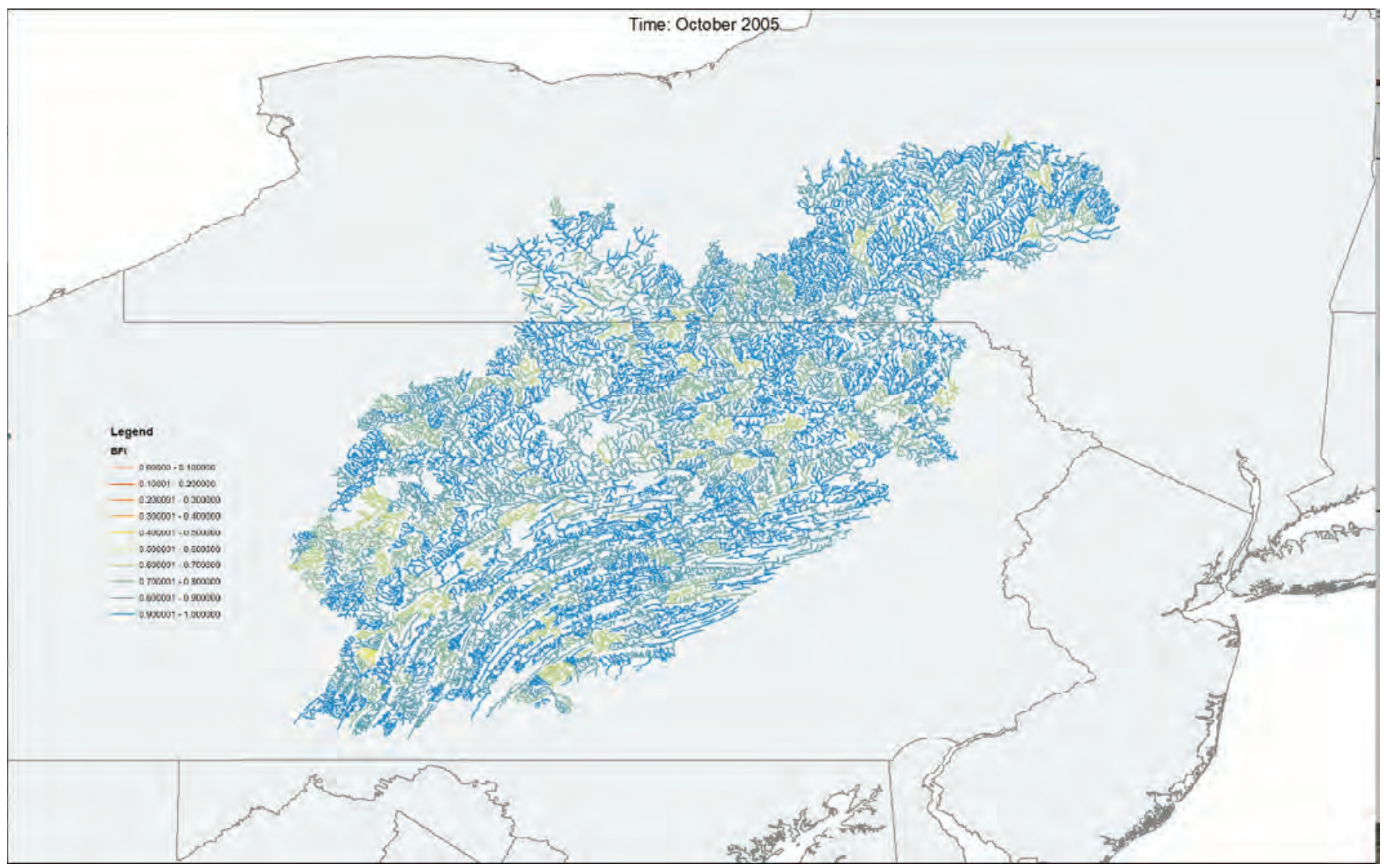

Figure 16. The first frame of the monthly base-flow index (BFI) animation for the watershed of the Susquehanna River, upstream from Harrisburg, Pennsylvania. View animation at https://doi.org/10.3133/sir20205055. 


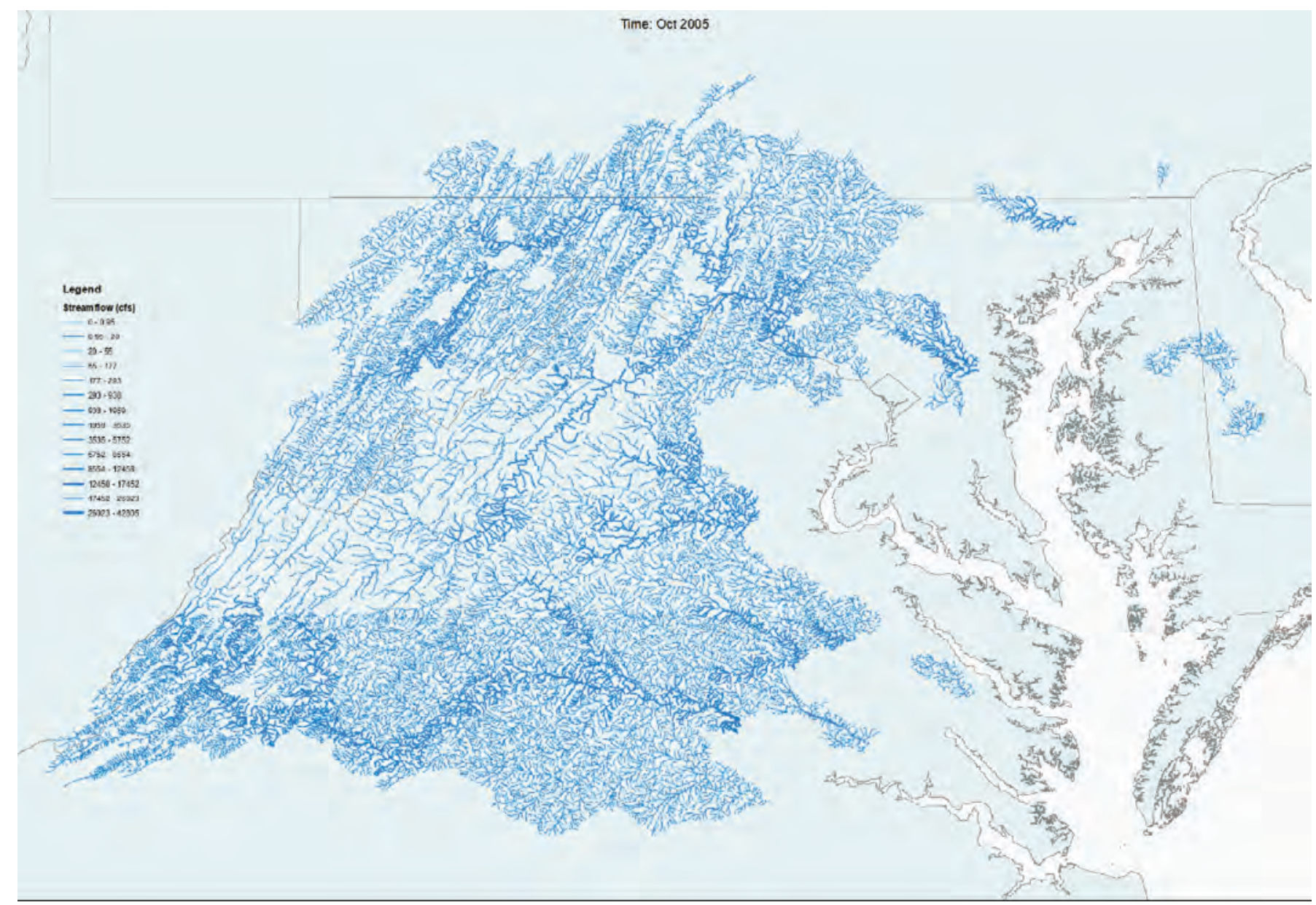

Figure 17. The first frame of the monthly mean streamflow animation for the nontidal Chesapeake Bay watershed outside of the Susquehanna watershed. View animation at https://doi.org/10.3133/sir20205055. 


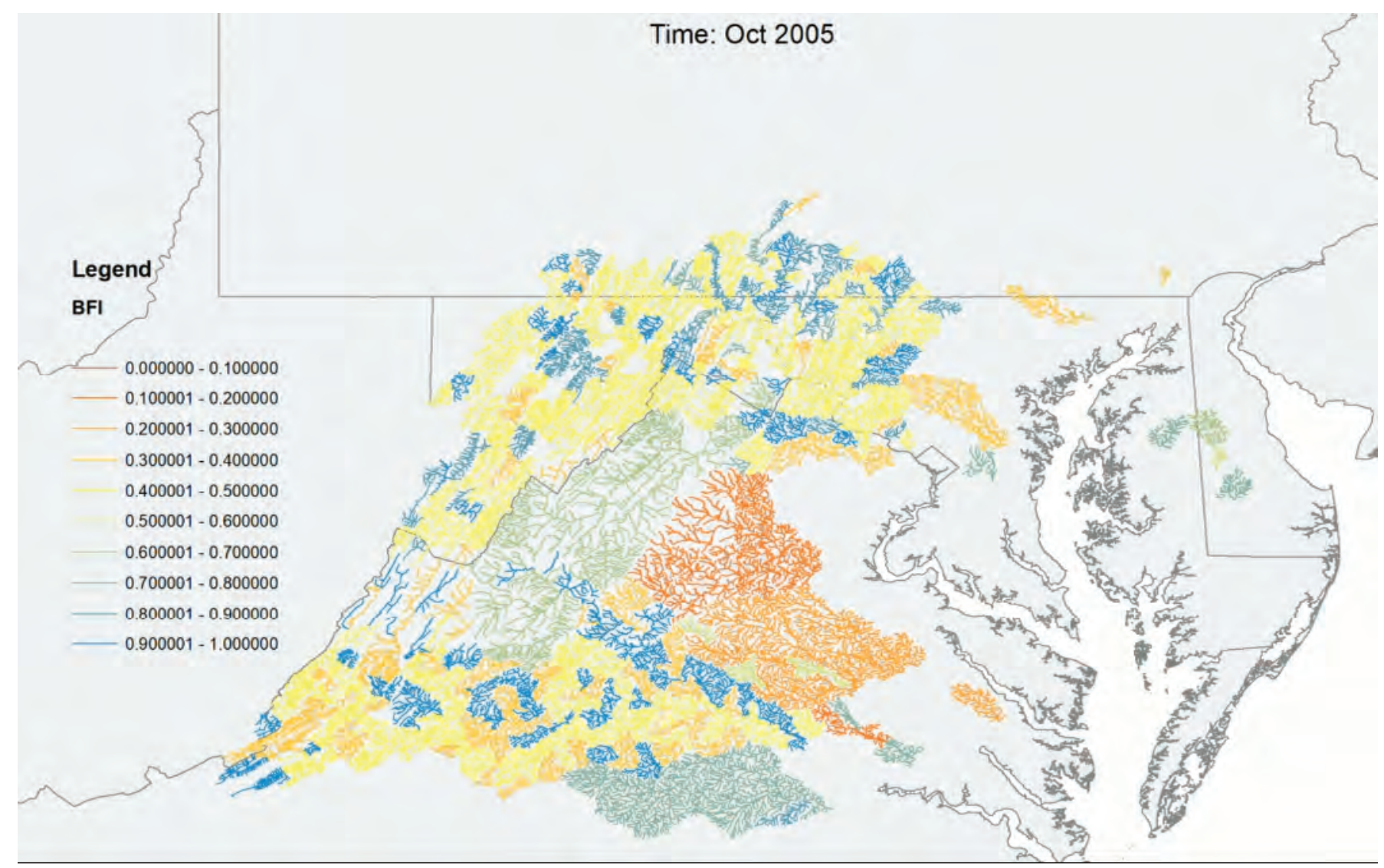

Figure 18. The first frame of the monthly base-flow index animation for the nontidal Chesapeake Bay watershed outside of the Susquehanna watershed. View animation at https://doi.org/10.3133/sir20205055. 
the localization of storms, which increased runoff and, thus, reduced the base-flow index.

\section{Summary}

The daily mean streamflow for all the nontidal parts of the Chesapeake Bay riverine system with the Unit Flows in Networks of Channels computer application using measured streamflow at the most downstream gage of selected rivers. The streamflows estimated by the Unit Flows in Networks of Channels computer application were aggregated at the 12-digit Hydrologic Unit Code level, after which base flow was estimated by two hydrograph-separation methods. Based on six sites selected for comparison, modeled streamflows are typically within an order of magnitude of measured streamflows, and monthly mean streamflows are in better agreement than daily streamflows. For the six selected sites, the base-flow values calculated by the two hydrograph-separation methods were compared. The monthly base-flow values also were in better agreement than the daily base-flow values. The modeled data were animated to better visualize spatial and temporal variability of streamflow and base-flow index.

\section{References Cited}

Buffington, P.C., Capel, P.D., and Hopple, J.A., 2020, Datasets and scripts used for estimating streamflow and base flow within the nontidal Chesapeake Bay riverine system, water years 2006-15: U.S. Geological Survey data release, https://doi.org/10.5066/P906K5GZ.

Collischonn, W., and Fan, F.M., 2013, Defining parameters for Eckhardt's digital base flow filter: Hydrological Processes, v. 27, no. 18, p. 2614-2622. [Also available at https://doi.org/10.1002/hyp.9391.].

Eckhardt, K., 2005, How to construct recursive digital filters for base flow separation: Hydrological Processes, v. 19, no. 2, p. 507-515, accessed February 1, 2017. https://doi.org/10.1002/hyp.5675.

Holtschlag, D., 2018, UFINCH-A method for simulating unit and daily flows in networks of channels described by NHDPlus using continuous flow data at U.S. Geological Survey streamgages: U.S. Geological Survey Scientific Investigations Report 2016-5074, 17 p. [Also available at https://doi.org/10.3133/sir20165074.].
Horizon Systems Corporation, 2017, NHDPlusV2 data: Horizon Systems Corporation, NHDPlus Version 2 web page, accessed April 5, 2017, at http://www.horizonsystems.com/NHDPlus/NHDPlusV2_data.php.

MathWorks, Inc., 2018, MATLAB: MathWorks, Inc., accessed September 28, 2018, at https://www.mathworks.com/products/matlab.html.

Nash, J.E., and Sutcliffe, J.V., 1970, River flow forecasting through conceptual models. Part I-A discussion of principles: Journal of Hydrology (Amsterdam), v. 10, no. 3, p. 282-290. [Also available at https://doi.org/10.1016/0022-1694(70)90255-6.].

Raffensperger, J.P., Baker, A.C., Blomquist, J.D., and Hopple, J.A., 2017, Optimal hydrograph separation using a recursive digital filter constrained by chemical mass balance, with application to selected Chesapeake Bay watersheds: U.S. Geological Survey Scientific Investigations Report 2017-5034, 51 p. [Also available at https://doi.org/10.3133/sir20175034.].

Santhi, C., Allen, P., Muttiah, R., Arnold, J., and Tuppad, P., 2008, Regional estimation of base flow for the conterminous United States by hydrologic landscape regions: Journal of Hydrology (Amsterdam), v. 351, no. 1-2, p. 139-153. [Also available at https://doi.org/10.1016/j.jhydrol.2007.12.018.].

U.S. Geological Survey, 2020, USGS water data for the Nation: U.S. Geological Survey National Water Information System database, accessed June 15, 2020, at https://doi.org/10.5066/F7P55KJN.

U.S. Geological Survey and U.S. Department of Agriculture, Natural Resources Conservation Service, 2013, Federal standards and procedures for the National Watershed Boundary Dataset (WBD) (4th ed.): U.S. Geological Survey Techniques and Methods, book 11, chap. A3, 63 p. [Also available at https://pubs.usgs.gov/tm/11/a3/.]

Wahl, K.L., and Wahl, T.L., 1995. Determining the flow of Comal Springs at New Braunfels, Texas-Proceedings of the First International Conference on Water Resources Engineering, San Antonio, Tex., August 16-17, 1995: American Society of Civil Engineers, p. 77-86. [Also available at https://www.usbr.gov/tsc/techreferences/ hydraulics_lab/pubs/PAP/PAP-0708.pdf.] 
For more information about this publication, contact: USGS National Water-Quality Assessment (NAWQA) Science Team 12201 Sunrise Valley Drive

Reston, VA 20192

For additional information, visit: https://water.usgs.gov/nawqa/

Publishing support provided by the Rolla and Sacramento Publishing Service Centers 


\section{㞭}

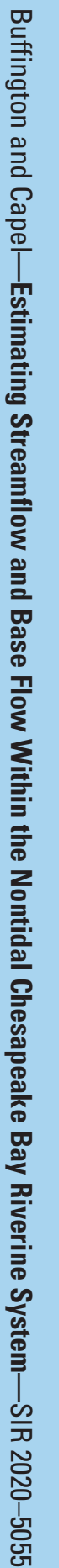

